Policy Research Working Paper 2802

Telecommunication

Reforms, Access Regulation,

and Internet Adoption in Latin America
Unresolved regulatory issues,

particularly those relating to

interconnection agreements,

hamper progress in Internet

adoption in Latin America.

Antonio Estache

Marco Manacorda

Tommaso M. Valletti

The World Bank

World Bank Institute

Governance, Regulation, and Finance Division

March 2002 


\section{Summary findings}

Estache, Manacorda, and Valletti review the stylized facts on regulatory reform in telecommunications and its effects on telecommunications development and Internet penetration in Latin America. Relying on data from the International Telecommunication Union, the Information for Development Program (InfoDev), and the World Bank for 1990-99, the authors then test econometrically the determinants of the differences in Internet penetration rates across Latin America.

The results show that effective implementation of the reform agenda in telecommunications regulation could accelerate adoption of the Internet in Latin Americaeven though it is only part of the solution (income levels, income distribution, and access to primary infrastructure are the main determinants of growth in Internet connections and use).

Regulation will work by cutting costs. Cost cutting will require that regulators in the region take a much closer look at the design of interconnection rules and at the tradeoffs that emerge from the complex issues involved. It will also require a commitment to developing analytical instruments, such as cost models, to sort out many of the problems. Appropriate cost rnodels will generate benchmarks that are much more consistent with the local issues and with the local cost of capital than international benchmarks will ever be for countries in unstable macroeconomic situations. Cost cutting will require an equally strong commitment to imposing regulatory accounting systems that reduce the information asymmetries that incumbents use to reduce the risks of entry.

All these changes will ultimately require a stronger commitment by competition agencies, since in many countries a failure to negotiate interconnection agreements will raise competition issues just as often as it will raise regulatory questions.

This paper-a product of the Governance, Regulation, and Finance Division, World Bank Institute-is part of a larger effort in the institute to increase understanding of infrastructure regulation. Copies of the paper are available free from the World Bank, 1818 H Street NW, Washington, DC 20433. Please contact Gabriela Chenet-Smith, room J3-304, telephone 202473-6370, fax 202-676-9874, email address bchenet@worldbank.org. Policy Research Working Papers are also posted on the Web at http://econ.worldbank.org.The authors may be contacted at aestache@worldbank.org, m.manacorda@lse.ac.uk, or t.valletti@ic.ac.uk. March 2002. (42 pages)

The Policy Research Working Paper Series disseminates the findings of work in progress to encourage the exchange of ideas about development issues. An objective of the series is to get the findings out quickly, even if the presentations are less than fully polished. The papers carry the names of the authors and should be cited accordingly. The findings, interpretations, and conclusions expressed in this paper are entirely those of the authors. They do not necessarily represent the view of the World Bank, its Executive Directors, or the countries they represent. 


\title{
TELECOMMUNICATION REFORMS, ACCESS REGULATION, AND INTERNET ADOPTION IN LATIN AMERICA ${ }^{1}$
}

\author{
Antonio Estache, The World Bank and ECARES \\ Marco Manacorda, Queen Mary College and CEP, London School of Economics \\ Tommaso M. Valletti, Imperial College and CEPR
}

\section{INTRODUCTION}

Latin America is betting on the potential "new economy" productivity payoffs from telecommunications reform. It wants fast improvements in the quantity and quality of its information and communications technology. Chile's Telecommunication Subsecretariat optimistic growth target estimate issued in mid 2000 for fixed line, mobile phone services and internet products for the next decade is quite illustrative. ${ }^{2}$ By 2010 , it expects fixed phone penetration to more than double to reach $49 \%$, mobile penetration to triple to $60 \%$ and internet access to quadruple to about $50 \%$ of the population. ${ }^{3}$ Similar statements made by key policymakers from Argentina to Mexico suggest that this optimism is shared throughout the region. The underlying assumptions are: (1) the liberalization of the sector has progressed enough to allow the countries of the region to now make the most of cheaper technologies and lower costs of access to web enabled telecommunications technologies and services; (2) once supply has increased enough, most policymakers expect demand to follow quickly thanks to the diffusion of the new technologies throughout the region which requires very little input from the government besides ensuring the liberalization of the telecoms sector and (3) this should significantly contribute to close the gaps between the poorest and the richest across and within countries. ${ }^{4}$

\footnotetext{
${ }^{1}$ We are grateful to M. Celani, E. Engel, L. Guasch, A. Galetovic, B. Mueller and P. Noumba for useful feedback on an earlier version. The views expressed in this paper are however our own and should not be attributed to any of the institutions we are affiliated with. Any mistake is obviously ours and ours only. 2 Latinc om (2000), "Chile's optimism greeted with skepticism", October 6"

${ }^{3}$ For comparison purposes, currently, $41 \%$ of the US population has a computer.

${ }^{4}$ Some authors have serious doubts that these benefits will be evenly distributed and talk about the risks of a digital divide among nations without an explicit government intervention. See Norris (2000) and Rodriguez and Wilson (2000). This is not addressed in this paper.
} 
The generalized optimism underlying these assumptions seems somewhat excessive for now. The main purpose of this paper is to show that there is still a strong role for the government in the sector to make sure that the new economy spreads its expected benefits throughout the region. Indeed, the paper shows that competition is not that great yet in Latin America's telecom sector. Moreover, we show that much needed regulation, in particular in the area of interconnection rules, still needs to be introduced in the non-competitive segments of the business if the telecommunications sector is to be competitive enough. Effective competition and regulation are particularly important if telecom reforms are going to allow the new economy to yields gains for everyone.

The empirical analysis of this paper shows that regulatory actions is needed because once one accounts for unobserved country specific characteristics, there is little evidence to support the view that an exogenous internet diffusion process is taking place in Latin America. In other words, this evidence - and our results are necessarily limited by the paucity of the available data - makes a case for the need of policy interventions, in particular in terms of access to phone lines (fixed or mobile) that are still lacking in the region. In that context, we show how the main regulatory determinants of access rules in Latin America drive the odds of integration of networks and hence the incentives for investments in telecommunications infrastructure needed to sustain the diffusion of internet in the region.

The paper is organized as follows. We first review some stylized facts on reform and its effects on the level of telecommunications and internet penetration in the region as a weak test of the widespread "cyber-optimism" of its politicians (section 2). In section 3, we test econometrically the determinants for the differences in internet penetration rates around the world and in the region, including tests of the importance of regulation as a determinant of cross-country differences in Latin America. In section 4, we summarize some of the main regulatory issues that will have to be addressed by telecoms regulators in the region. The section provides the main lessons from the theory relevant to the outstanding regulatory agenda in the region. In particular, we highlight all the issues regulators must consider when designing interconnection agreements. Section 5 concludes.

\section{WHAT ARE THE OUTCOMES OF A DECADE OF INSTITUTIONAL CHANGES?}

A combination of the poor historical performance of the public enterprises which had traditionally been running the sector, of fiscal crisis slowing down government financing of their investment deficits and new opportunities allowed by technological progress have 
resulted in major institutional changes in the sector. The 1990s have seen all countries in the region essentially adopt new laws aiming at liberalizing telecoms and have implemented them at least partially, with the major exceptions of Uruguay and Costa Rica. Moreover, out of the 20 countries sample covered by Table 1 , about $75 \%$ have fully or partially privatized the historical operator. ${ }^{5}$

The goal was also to introduce competition at least gradually. The dissemination of cellular phones, the opportunities for call backs and other technology changes forced competition into the sector in many countries. Most have some degree of competition although often with restrictions. This can be seen in the generous exclusivity periods for the first entrants in the business after privatization. These first entrants were typically strategic investors which took some risks and wanted some protection for those risks, at least during the early 1990s. In exchange, governments demanded investment commitments to improve coverage and service quality. The main exception has been Uruguay where a 1992 referendum resulted in the rejection of changes in the sector and in particular of its liberalization. In some other countries, including Costa Rica, Ecuador and Honduras, political and economic problems postponed the actual reforms but Table 1 shows that the major laws have already been introduced.

An additional important change has been the creation of independent regulatory agencies. Table 1 reveals that in most countries these agencies are sector specific and are accountable to a ministry rather than to the head of state or to the parliament. In many countries, the main threat to their independence from political interference results from their lack of financial autonomy. As long as a minister is expected to sign off a budget transfer to finance the regulator's expenses, there is a risk of conflict of interest in regulatory decisions.

The final institutional change worth mentioning is the one that has not happened yet! While basically all countries have in fact introduced the appropriate legislation and while most of the regulators have defined the basic regulatory principles they intend to follow on most issues, the supporting regulatory analysis is still lagging. Take the example of the regulatory regime. Most Latin American countries have decided to rely on a price cap which implies that the regulator must have some idea of the efficiency gains realized by the operators since this gain will eventually have to be shared with the users. No country has yet defined the methodology to be followed to assess these gains, leaving the regulatory decision open to negotiation. Regulatory gaps like this one seem not to have had dramatic impacts in

\footnotetext{
5 All the data used and quoted in this document is from the ITU data base unless otherwise specified.
} 
the region, probably because of the combination of a competitive international environment and of continuous technical changes which drive costs and tariff down.

All in all the outcome associated with the reforms has been quite impressive so far. Table 2 summarizes key performance changes during the 1990s. These are dramatic reflecting the joint effects of reform and of technology changes - but are not sufficient. For instance, even if the growth in the number of phones $/ 100$ inhabitants has increased by close to $40 \%$ between 1996 and 2000 , phone penetration is still only about $25 \%$ of what it is in high income countries (31 residential main lines per 100 households in 1998 for Latin America and the Caribbean vs. 113 for North America). The gap in access to phone services is however closing with the acceleration in the penetration of the cellular phones - from 100,000 in 1990 to 39 million in 1999. One in every 4 phone users in Latin America now relies on mobile. In Paraguay and Venezuela, cell users outnumber fixed phone users. Also, service quality has improved. For instance, faults are dropping and waiting times to get new phones continue to decrease (in fact, they have converged to zero as many users can now simply get a mobile phone). And finally, connection fees and subscription charges are falling as well, completing the overall positive impression on the outcomes of the reform.

There are also problems. First, most governments in the region do not seem to appreciate that getting the "privatization" deals done is the easy part. Introducing and enforcing a regulatory regime that results in outcomes mimicking the effects of competition is the hard part and most governments tend to underestimate its importance. Indeed, while restructuring and privatization have taken place quite successfully in most countries of the region, the implementation of the regulatory agenda needed to ensure the full potential reform payoffs is still lagging and competition continues to be restrained in many subtle ways. For instance, Latin America counts many Internet Telephony Service Providers (ITSPs) which capture both terminating and originating long distance traffic. These could put competitive pressure on traditional licensed operators. Some countries such as Argentina initially prohibited explicitly ITSPs from offering voice over packet (VoP) services viewing them as telecommunications services which are subject to licenses as traditional circuit-switched long distance services or as valued added services subject to their own set of rules. Others such as Chile have quickly legalized VoP, raising the issue of discrimination since these companies may not have the same service obligations as traditional operators. Most others have not yet issued opinions on the matter, in the best cases leading to a wait and see strategy by potential entrants and in the worst cases leading to conflicts such as in Colombia where the gradual approach to market liberalization appears to be interfering with the much faster technological 
progress. The cellular operator COMCEL started selling VoP services without a long distance license. All the existing long distance carriers who had paid the required $\$ 150$ million for that license sued immediately revealing the difficulties of building a dynamic vision of competition in this environment with changing technologies.

Second, high prices continue to be perceived as an issue in the region. To a large extent this is a result of the limited.competition in the sector. For most countries, the exclusivity periods granted to get the privatization deals done resulted in lasting high connection and usage tariffs. Table 2 shows that indeed residential connection rates continue to be high when compared to the US even if they have gone down significantly. These exclusivity periods are now coming to an end as in Argentina or Venezuela and this should lead to a reduction in tariffs driven by the market. However, most countries have not yet defined the rules of the game to ensure competition in a sector where costing the access to bottleneck facilities continues to be at the core of the regulatory debate. Section 4 is devoted to this key aspect.

Finally, there are concerns that tariffs may not have dropped enough and that demand from the poorest is likely to be rationed, a consequence of the continued Latin American income distribution problem. As of mid-1999 for instance, only 10-15\% of the population had the resources to get on line. ${ }^{6}$ This is not a random fact. A study of the distribution of the gains from utilities privatization in Argentina conducted in 1999 already suggested that unless regulation was effective in redistributing the gains to all users, reform mostly benefited the local co-owners of privatized assets (Chisari et al., 1999). In terms of the access to new technologies, this implies that unless service obligations and ability to pay constraints are built in regulatory decisions, there is a reasonable risk that the distribution of the benefits of reforms will reflect the current distribution of wealth. ${ }^{7}$ Section 4 discusses the instruments that could be used to achieve redistribution, e.g. via general taxation or sector specific service obligations.

${ }^{6}$ Latincom (1999), "Mass market internet still some way off in Latin America", June $16^{\text {th }}$, p. 5.

${ }^{7}$ See the related WIDER research program and also Estache, Foster and Wodon (2001), and Estache, GomezLobo and Leipziger (2001). 


\section{WHAT DRIVES CROSS-COUNTRY DIFFERENCES IN INTERNET ACCESS?}

\section{1 A naïve look at the facts}

Internet has the potential to provide a wide array of benefits, ranging from education to business opportunities, hence it is crucial to understand how people have access to it. Internet subscriber penetration across Latin America is about $1 \%$. About $98 \%$ of these connections in 1999 where through analogue modems. This correlation between telecoms access and internet access is illustrated in Figure 1 for a sample of 20 Latin American countries in 1999. The linear trend line provides quite a good fit.

Figure 1. A naïve correlation between telecoms access and internet use

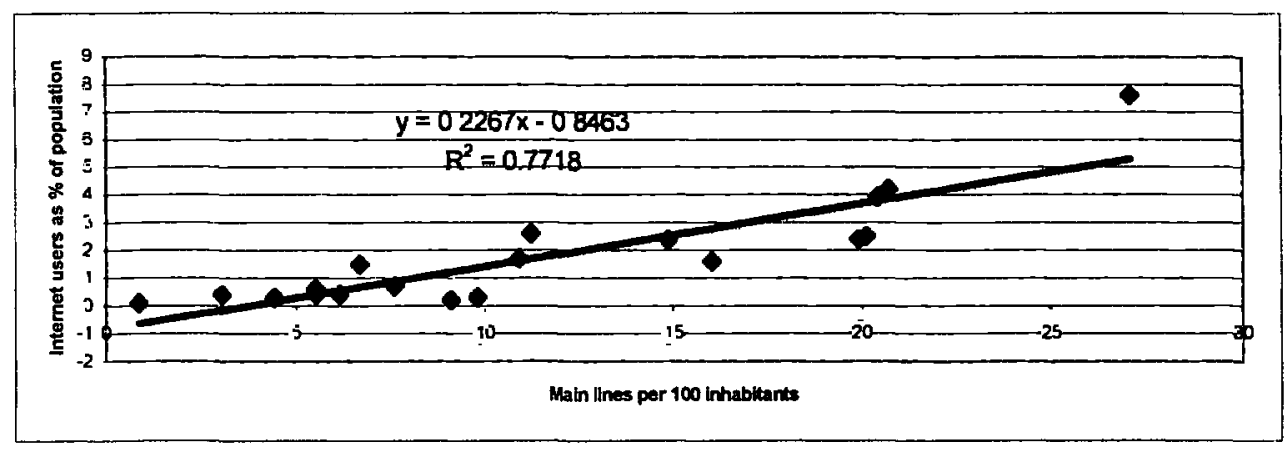

Table 3 summarizes some indicators available for Latin America on the spread of internet access in the region. It is interesting to be reminded that for a large majority of the countries of the region, internet access dates from the second half of the 1990s. ${ }^{8}$ Table 3 shows that the number of internet service providers (ISPs) is generally high enough in most countries to suggest that competition is generally not a major issue in this specific activity. But usage charges continue to be quite high. In 1999, the average cost to be on line combining ISP costs and local call charges was US\$ 52 , twice the equivalent cost in the USA.

Table 3. Indicators of potential access to the internet

\begin{tabular}{|l|l|l|l|l|l|l|l|}
\hline & $\begin{array}{l}\text { Internet } \\
\text { access } \\
\text { since: }\end{array}$ & $\begin{array}{l}\text { ISPs } \\
(1999)\end{array}$ & $\begin{array}{l}\text { Internet } \\
\text { hosts/10000 } \\
\text { inhabitants } \\
(2000)\end{array}$ & $\begin{array}{l}\text { Internet } \\
\text { users as \% } \\
\text { of pop. } \\
(1999)\end{array}$ & $\begin{array}{l}\text { Internet charges in } \\
1999 \text { (US\$ } \\
\text { monthly cost of 20 } \\
\text { hours off peak) }\end{array}$ & $\begin{array}{l}\text { Personal } \\
\text { computers } \\
(000 \mathrm{~s}) \\
(1999)\end{array}$ & $\begin{array}{l}\text { Cable TV } \\
\text { subscribers } \\
(000 \mathrm{~s})(1999)\end{array}$ \\
\hline Argentina & 1989 & 170 & 38.48 & 2.5 & 27.9 & 1,800 & 5890 (in 1998) \\
\hline Bolivia & Jul. 95 & 9 & 1.14 & 0.4 & 15.07 & 100 & 70 \\
\hline
\end{tabular}

\footnotetext{
${ }^{8}$ As a side result of the differences in penetration rates, 1999 business to business transactions in Latin America were estimated at about US\$ 288 million, with about 2/3 concentrated in Argentina, Brazil and Mexico. The equivalent figure for the US was US\$ 114 billion. See Morgan Stanley Dean Witter (2000), The Latin America Internet Report, February
} 


\begin{tabular}{|l|l|l|l|l|l|l|l|}
\hline Brazil & 1994 & 280 & 26.22 & 2.4 & 12.24 & 6,100 & 1,932 \\
\hline Chile & Jan. 92 & 26 & 26.42 & 4.2 & 19.12 & 1,000 & 656 \\
\hline Colombia & May 94 & 15 & 9.59 & 1.6 & & 1,400 & 613 (in 1998) \\
\hline Costa Rica & Jan. 93 & 2 & 20.47 & 3.9 & 20 & 400 & 75 \\
\hline Dom. Rep. & Jun. 95 & & 7.89 & 0.3 & & & \\
\hline Ecuador & Jan. 93 & 9 & 1.52 & 0.2 & 25 & 250 & 200 (in 1998) \\
\hline El Salvador & Jan. 96 & 7 & 1.54 & 0.7 & 11.4 & 100 & 277 \\
\hline Guatemala & Dec. 95 & 10 & 8.3 & 0.6 & 22 & 110 & \\
\hline Haití & Nov. 96 & & & 0.1 & & & \\
\hline Honduras & Jan. 96 & 17 & 7.6 & 0.3 & 40 & 60 & \\
\hline Jamaica & Aug. 94 & 20 & 39.4 & 2.4 & & 110 & 251 (in 1998) \\
\hline México & 1989 & 148 & 40.88 & 2.6 & 25.51 & 4,300 & 1,984 \\
\hline Nicaragua & Feb. 94 & 7 & 2.04 & 0.4 & 19.48 & 40 & 310 \\
\hline Paraguay & 1996 & 22 & 3.02 & 0.4 & & 60 & 95 \\
\hline Peru & Feb. 94 & 54 & 3.0 & 1.5 & 21.99 & 900 & 380 \\
\hline Uruguay & Aug. 93 & 12 & 76.09 & 7.6 & & 330 & 400 \\
\hline Venezuela & 1994 & 32 & 5.91 & 1.7 & & 1,000 & 600 (in 1998) \\
\hline
\end{tabular}

Source: ITU

One of the most obvious explanations for the continued high costs is the fact that there still are strong impediments to effective competition. Anecdotal evidence would tend to confirm this line of reasoning. For instance, in Brazil, which counts about $50 \%$ of all Latin American users, the high delivery costs for IP service results from the near monopoly position of the incumbent on international gateways. This is a problem for most potential entrants and for users which requires the creativity of service providers in finding various ways to finance their services. One example is Bradeco Bank. It introduced a free access internet service in December 1999, in an attempt to adopt a business model based on advertising fees. The option that seems to be most widely adopted is revenue sharing with local telcos, following the European model. This solution will require some regulatory intervention since in many countries local telecoms are also ISPs $^{9}$ and unlikely to work out deals that may hurt that part of their business.

There are of course other issues revealed by Table 3 . The clearest among those is that PC penetration continues to be quite low. The percentage of the population who owns a PC varies between 5 and $10 \%$ depending on the country. The equivalent share is about $50 \%$ in the US or around $20 \%$ in Spain or Portugal for instance. 10 While cable TV does offer an alternative to phone connections to the internet, analysts do not expect this access mode to represent an immediate viable solution. 11 ,

\footnotetext{
9 Think of the case of Telefonica who owns Terra Livre, a free internet access provider.

${ }^{10}$ Morgan Stanley Dean Witter (2000), The Latin America Internet Report, February.

11 Latincom quotes forecasts predicting a $20 \%$ share of potential internet access using cable TV by the year 2010; see Latincom (2000), "TV sector primed for growth as economic recession lifts", June $5^{\text {th }}$. The equivalent figure is currently $40 \%$ in the UK and already above $20 \%$ in Spain or the European Nordic countries.
} 
A comparison of the various pieces of information provided in table 3 provides also some interesting stylized facts on the linkages between reform, income levels and internet access. First, two of the largest users of the internet (Uruguay and Costa Rica) have not restructured their telecoms sector, suggesting that the correlation between telecom restructuring and sector performance is not 1 . The fact that both countries are small and close to countries which have undertaken major liberalizations, thus providing service alternatives, still hints to appropriate competitive environments as key drivers. Second, the table gives the impression that internet appears to be something for the rich. Figure 2 makes this impression more visual by showing the cross-sectional correlation between GDP per capita and internet access. The correlation between average income levels and internet access is indeed quite obvious. This tends to confirm the analysis of Norris (2000). Using a cross-section of 179 nations, she regresses the number of people online on variables measuring economic, social and political development. She finds that only GDP per capita and the share of R\&D spending in GDP turned out to be statistically significant. Her point is that economic factors outweigh all others in predicting cross country differences in internet usage.

Figure 2. A naïve correlation between internet access and GDP/capita

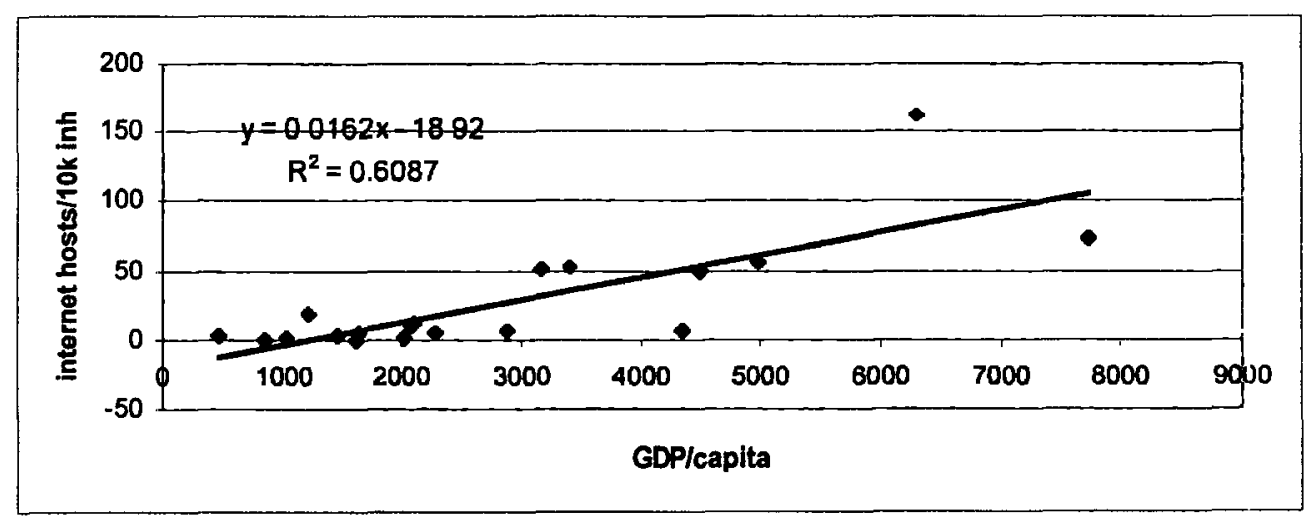

Combining the information in Table 3 with the WIDER data base on income distribution provides further food for thought on the use of internet. Chile, Costa Rica and Uruguay are the top three users. It turns out that Costa Rica and Uruguay have among the least uneven income distribution in the region while Chile is a country in which even if income distribution has remained stable, poverty has been declining significantly in recent years. This would suggest that income distribution also matters. Figure 3 once more provides a simple visual impression. While it is not as convincing as Figure 2, it hints at a negative 
correlation between internet access and an indicator of inequality in income distribution such as the Gini coefficient.

Figure 3. A naïve correlation between internet use and income distribution

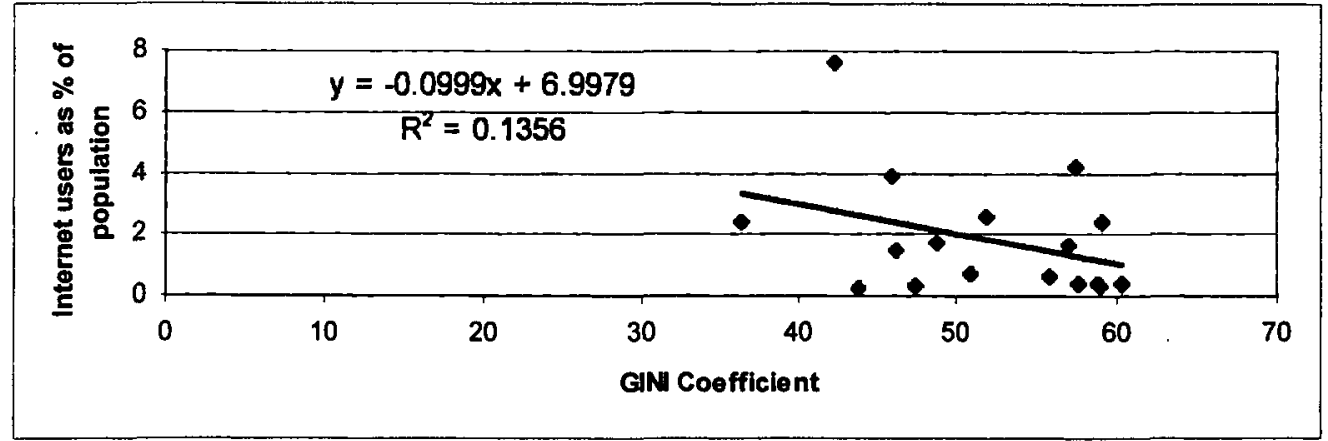

Overall, these stylized facts are a first attempt to qualify the more blurred notion of a digital divide. Income is what matters most. A richer country is expected to have more internet users. Perhaps a more subtle result is that, for a given level of average income, an additional dollar given to the poor more than compensates for the diminished internet use made by the rich from whom a dollar is taken away, resulting in an overall increase in internet access.

\subsection{A more formal look at the facts}

In the remaining part of this section, we conduct a multivariate analysis to investigate if these findings still emerge after a closer scrutiny, once additional factors are also taken into consideration. We are also interested in trying to track down the relevance of policy variables. We estimate a simple regression building on the naïve correlations just discussed as well as on additional information on internet access costs and on access to complementary equipment (e.g. computers) as determinants of growth in internet access and use. While the naive correlations in the preceding section exploit the cross country differences in internet diffusion at one point of time, in the rest of the analysis we use longitudinal data which allows to control for country (and, at times, continent) fixed effects which are potentially correlated with the dependent variables and might lead to biased estimates of the effect of technology and growth on internet diffusion. By allowing for country specific fixed effects we attempt to purge our estimates of the effect of unobserved differences in internet diffusion across 
countries, due, among others, to permanent differences in educational attainment and institutions. ${ }^{12}$

In this context, the inclusion of access costs is quite crucial since one of the main regulatory issues in the telecom sector is the design of interconnection access rules and its implications for access costs. We also test if a model of technological diffusion based on epidemic theories of diffusion may explain internet access in Latin America. In our tests, we use two samples of data. The first is for the whole World, testing for any regional specificity for Latin America. The second focuses on Latin America only, making full use of the additional institutional and technological information available for that region. The number of explanatory variables is drastically restricted by the data available, however we do feel that the data bases are good enough to generate some useful policy insights.

The specific model we use for the whole world is the following:

$$
\ln \mathrm{H}_{i t}=\mathrm{a}_{0}+\mathrm{a}_{1} \ln \mathrm{Y}_{\mathrm{it}}+\mathrm{a}_{2} \ln \mathrm{P}_{\mathrm{it}}+\mathrm{a}_{3} \ln \mathrm{L}_{\mathrm{it}}+\mathrm{a}_{4} \ln \mathrm{C}_{\mathrm{it}}+\mathrm{a}_{5} \ln \mathrm{H}_{\mathrm{it}-1}
$$

where, for a generic country $i$ in year $t$ :

H: per-capita number of Internet hosts (Internet users in the second set of regressions),

Y: per-capita GDP,

P: internet access cost, defined as the sum of 30 3-minutes local calls plus monthly phone subscription rates,

L: per-capita digital fixed telephone lines,

C: per-capita Personal Computers.

The tests that focus on Latin America extend model (1) to include additional regressors, namely whether or not the incumbent operator is privatized in a given year and whether or not an independent regulator is present in a given year. In some specifications, we also control for the degree of income inequality as measured by the Gini coefficient. ${ }^{13}$

In order to check for the robustness of our results, model (1) (and its extension for Latin America) is estimated twice, using two different dependent variables $H$. In the first one, we use Internet hosts, while in the second one we employ Internet users (taken from a

\footnotetext{
12 For a recent survey of the concept and empirical importance of international technology diffusion see $\mathrm{W}$. Keller (2001)

13 Data on Gini come from the Wider database. Because data are not available each year, we have interpolated the actual series with a linear trend and used the estimated value as a regressor.
} 
different source). ${ }^{14}$ The estimates refer to the period 1990-99. Data come from the ITU/BDT database and from infoDev. All money variables (GDP and costs) are expressed in US\$.

Eq. (1) is fairly standard and only the last term (dependent lagged variable) deserves some further comment. Such term comes from a Gompertz model of technology diffusion, quite common in the estimation of the sales of relatively new products. It derives after positing that the number of new adopters of a certain good or service in a given period depends both on the maximum number of potential users (usually a fraction of the total population) and on the number of existing users that may "spread" further adoption. These models typically produce life-cycle diffusion curves over time, with an introductory phase characterized by slow growth, a growth phase reflecting the highest rate of consumer acceptance, and a maturity phase where the product reaches its point of saturation. The Gompertz and the Logistic curves are probably the most popular in a wider class of curves. ${ }^{15}$

Epidemic models can be criticized on several grounds, mainly because they posit an exogenous process that does not model explicitly demand and supply factors, relying on primitive treatments of information acquisition. We simply intend to check if the lagged dependent variable resulting from the stock adjustment process reflects a diffusion process for the internet. If such process is found in the data, one could be tempted to argue that Latin America is currently not doing particularly well simply because it started the adoption process relatively late in time. If there are some forces that drive an exogenous process of diffusion (perhaps not well specified, e.g. imitation), internet adoption should then converge towards an equilibrium level, raising the further question on the rate of convergence. Our exercise is also motivated by recent work of Kiiski and Pohjola (2001) who used a Gompertz model to test Internet diffusion in OECD countries and in the whole world. The basic difference between our approach and Kiiski and Pohjola's is that by using the panel structure of the data, we can control for unobserved country specific characteristics that are potentially correlated with the included regressors, and in particular with the lagged dependent variable.

In eq. (1) the coefficient $a_{5}$ of the lagged dependent variable should give information on the diffusion process. If there is diffusion, it is expected to be positive but smaller than 1 . In the absence of diffusion, the coefficient should be 0 .

The models are estimated via GLS with weights given by country population. Standard errors are robust to arbitrary heteroskedasticity. Because of the bias of the within group

\footnotetext{
$14 \mathrm{~A}$ host is a domain name that has an IP address record associated with it. This would be any computer system connected to the Internet (via full or part-time, direct or dialup connections).

15 See Stoneman (1995) for a comprehensive survey.
} 
estimator when the lagged dependent variable is included on the right hand side, specifications including the lagged dependent variable and fixed effects are estimated via IV, using the Anderson-Hsiao estimator. In the regression for the world, the test for a Latin American specific effect is an F-test that the coefficients on the right hand side variables for the Latin American countries are jointly different from the coefficients for the rest of the world.

\subsection{The determinants of growth in internet hosts}

Table 4 summarizes the results of two regressions testing the determinants of internet hosts in the world. The first column ignores the possible diffusion and test for the relevance of time and country fixed effects. The second column summarizes the test of the diffusion model and thus include a lagged dependent variable. The models are estimated including additive continent and year specific dummies (to allow for allow for unobserved differences across continents plus worldwide macro economic shocks), their interaction (to allow for continent specific macroeconomic shocks) and additional country specific fixed effects, controlling for time invarying country specific characteristics. Similarly, when we run the regression for Latin America only we allow for additive year and country dummies. P-values are reported alongside the estimated coefficients.

A first important result emerging from the table is that the coefficient on the lagged dependent variable is not significantly different from zero. This suggests that the exogenous diffusion process found by Kiiski and Pohjola (2001) tends to disappear once fixed country effects are properly accounted for. On the other hand, the lagged dependent variable would be positive and significant if one allowed only for additive continent or year dummies (results are not reported here). For these reasons, specification 1 is our preferred one.

Table 4. Dependent variable: Ln hosts pc in the world

(first column is coefficient, second is p-value)
\begin{tabular}{|l|r|r|r|r|}
\hline & \multicolumn{2}{|c|}{1} & \multicolumn{2}{|c|}{2} \\
\hline $\begin{array}{l}\text { Lagged dependent } \\
\text { variable }\end{array}$ & & & -0.464 & 0.387 \\
\hline Ln Gdp pc & 0.713 & 0.033 & 0.935 & 0.122 \\
\hline Ln Costs & -0.345 & 0.109 & -0.505 & 0.213 \\
\hline Ln Lines pc & 0.573 & 0.062 & 0.758 & 0.068 \\
\hline Ln PC's pc & 0.878 & 0.007 & 0.642 & 0.179 \\
\hline & & & & \\
\hline R2 & 0.996 & & 0.993 & \\
\hline Obs. & 353 & & 353 & \\
\hline & & & & \\
\hline F-test for Latin America & 1.47 & 0.211 & 1.01 & 0.403 \\
\hline
\end{tabular}

All specifications control for additive year and continent effects, interactions of the two and country effects. 
Specification 1 confirms the impressions given by the stylized facts reviewed earlier. GDP/capita is an important predictor of internet diffusion. A $10 \%$ rise in per capita GDP is associated to about a 7\% rise in the number of hosts per capita, suggesting that the internet is a normal good. Access to basic infrastructure such as digital lines and PCs matter (they enter with the correct signs and are significant). A $10 \%$ PCs per capita is associated to a rise in hosts per capita of about $9 \%(\approx .878 * .1)$. Similarly, a $10 \%$ rise in fixed lines is associated to a rise in hosts percapita of about $5 \%\left(\approx .573^{*} .1\right)$. Finally, internet costs enter significantly and negatively. A $10 \%$ fall in costs is associated to a rise in hosts per capita of about $3 \%$. This suggests that regulators should indeed be concerned with policies aimed at lowering such costs, both directly via Universal Service Obligations in rural areas, and indirectly promoting competition among Service Providers and devising appropriate interconnection rules since in the majority of cases ISPs have to rely on the incumbent's local loop to supply their services to customers.

Table 4 also provides a test of any Latin-American specificity (F-test). The p-values are well above any standard critical value meaning that one cannot dismiss the idea that LA is similar to the rest of the world. Implicitly, these results suggest that once one adequately controls for unobserved country-specific characteristics which do not covary over time, the different performance of LA with respect to the rest of the world has mainly to be ascribed to differences in the evolution of the right hand variables rather than differences in the reaction parameters.

Table 5 summarizes the regressions focusing specifically on Latin America only. Here we also look at the effects of regulation and privatization as well as income inequality. The first two columns report the same regressions as in Table 4 using all the available information for LA (60 observations). In column 3 to 5 we report the results on a restricted sample (34 observations) corresponding to the county-year points for which data on Gini and the institutional variables are available. ${ }^{16}$

\footnotetext{
16 The countries in the restricted sample are: Argentina, Costa Rica, Ecuador, Jamaica, Honduras, Mexico, Nicaragua, Paraguay, Peru and Venezuela.
} 
Table 5. Dependent variable: Ln hosts pc in Latin America

\begin{tabular}{|c|c|c|c|c|c|c|c|c|c|c|}
\hline \multicolumn{11}{|c|}{\begin{tabular}{l|l} 
fficient, second is p-val \\
2
\end{tabular}} \\
\hline & \multicolumn{4}{|c|}{ entire sample } & \multicolumn{6}{|c|}{ Restricted sample } \\
\hline Lagged dependent variable & & & 0.257 & 0.602 & & & & & & \\
\hline Ln GDP pc & 1.822 & 0.001 & 1.703 & 0.001 & 1.887 & 0.013 & 2.219 & 0.004 & 2.460 & 0.002 \\
\hline Ln Costs & -0.410 & 0.282 & -0.321 & 0.407 & -0.956 & 0.004 & -0.759 & 0.028 & -1.012 & 0.016 \\
\hline Ln Lines pc & 1.227 & 0.043 & 1.021 & 0.076 & 2.255 & 0.067 & 2.231 & 0.011 & 2.094 & 0.072 \\
\hline Ln PC's pc & -1.062 & 0.381 & -1.248 & 0.348 & -3.395 & 0.037 & -4.836 & 0.008 & -6.294 & 0.009 \\
\hline In Gini & & & & & & & -10.149 & 0.039 & -13.870 & 0.010 \\
\hline Regulation & & & & & & & & & 1.061 & 0.070 \\
\hline Regulation*privatization & & & & & & & & & -1.076 & 0.093 \\
\hline Obs. & 60 & & 60 & & 34 & & 34 & & 34 & \\
\hline $\mathrm{R} 2$ & .984 & & .988 & & 988 & & .992 & & .994 & \\
\hline
\end{tabular}

All specifications control for additive year and country effects

The table confirms the rejection of the diffusion model for internet hosts. As before, once country fixed effects are taken into consideration, the lagged dependent variable is not significant. ${ }^{17}$ Interestingly the ln computer variable enters with a negative sign. One possible interpretation for this result is that the low internet diffusion is primarily explained by the absence of adequate infrastructures (fixed lines). At given fixed lines, a rise in the number of PCs tends to depress internet diffusion, possibly because of the congestion of the available lines. ${ }^{18}$

In column 3 we replicate the same specification as in column 1 on the restricted sample. The results are similar, although the value of the coefficients is somehow magnified. In column 4 , we control for the log of the Gini. Inequality seems to matter substantially: a $10 \%$ fall in the Gini (approximately one standard deviation increase), leads to a doubling of internet diffusion $\left(\approx 10.149^{*} .10\right)$. This is a remarkable effect. The other coefficients remain essentially unchanged and still significant.

\footnotetext{
17 Some caution must be exerted in the interpretation of the coefficient. The Anderson Hsiao estimator is consistent for $\mathrm{N}$ (Number of cross sectional observations) going to infinity. Clearly, when we restrict to Latin America only, we are short of fulfilling this condition. Some caution must be exerted in the interpretation of the coefficients. The Anderson Hsiao estimator is consistent for $\mathrm{N}$ (Number of cross sectional observations) going to infinity. Clearly, when we restrict to Latin America only, we are short of fulfilling this condition.

18 As noted by a referee, computers per capita might be endogenous to internet diffusion, since the more people use the internet, the higher will be the incentive for others to buy a PC, perhaps due to a demonstration or an externality effect. The direction of this bias, however, is likely to lead to an overestimate of the coefficient on log computers. Similarly, it is worth remarking that costs of access might be endogenous to internet growth. In this case, an increase in the number of hosts would lower access costs through higher competition. On the other hand, if higher access costs attract more providers, the bias would be in the opposite direction. Finally note that GDP per capita might itself be endogenous to telecommunications infrastructure since the latter can affect economic growth (Röller and Waverman, 2001). In this case, one would reasonably suspect that our estimate of the effect of GDP is upward biased. Unfortunately we do not have credible instruments for these variables.
} 
In column 5 we include the institutional variables on whether the sector is regulated or not and on whether this has been privatized, conditional on the sector being regulated.19 Interestingly, the results suggest that while regulation boosts internet diffusion, as soon as the sector is privatized, internet growth returns to the pre-regulation level.20

\subsection{The determinants of growth in internet use}

Rather than internet hosts, we now consider internet users (taken from infoDev) as our LHS variable. As before, first we look at the whole world (Table 6), then Latin America (Table 7). The results in Table 6 suggest again that there is no sign of diffusion with country fixed effects taken into account and specification 1 is the preferred one. Coefficients have the right sign, although they are less significant than before. The main engines of growth in internet users are access to PCs and to phone lines, while GDP and costs seem to matter less once fixed country effects are taken into account. A $10 \%$ rise in lines per capita tends to increase the number of internet users by about 2 and a half times as much. Also, an important additional difference with the focus on hosts is that the F-test could not reject the hypothesis that LA countries are jointly different in terms of the determinants of internet usage.

Table 6. Dependent variable: Ln internet users pc in the world

(first column is coefficient, second is p-values)

\begin{tabular}{|l|r|r|r|r|}
\hline & \multicolumn{2}{|c|}{1} & \multicolumn{2}{|c|}{2} \\
\hline Lagged dependent variable & & & -0.452 & 0.172 \\
\hline Ln Gdp pc & 0.236 & 0.606 & 0.363 & 0.565 \\
\hline Ln Costs & -0.173 & 0.503 & -0.297 & 0.383 \\
\hline Ln Lines pc & 0.801 & 0.299 & 2.061 & 0.118 \\
\hline Ln PC's pc & 2.182 & 0.000 & 2.580 & 0.001 \\
\hline & & & & \\
\hline Obs. & 383 & & 383 & \\
\hline R2 & 0.986 & & 0.976 & \\
\hline F-test for Latin America & 2.53 & 0.041 & 2.86 & 0.024 \\
\hline
\end{tabular}

All specifications control for additive year and continent effects, interactions of the two and country effects.

\footnotetext{
${ }^{19}$ Note that the privatization was preceded by the establishment of a regulator in all the countries covered by the sample but this is a somewhat misleading impression of the diversity in strength and independence of regulatory institutions. Argentina's regulator has grown to be significantly more competent during the 1990s to become one of the most capable towards the end of the period. Many others however have much more limited capacity to tackle the problems they are expected to address. In addition to regulatory endowment problems, capture has been and continues to be an issue in the region and hence the Levy-Spiller (1994, 1995 and 1996) concerns continue to be quite relevant even if they are not addressed explicitly here.

20 Again, some care must be exerted in interpreting these results, since it might well be possible that the full effects of regulation and privatization haven yet not taken place in LA.
} 
The model on internet use relying on more specific information on Latin America (Table 7) provides interesting additional insights. First, GDP and PC access are the dominating variables when compared to the determinants of internet hosts. This explains the rejection of the world-wide model for Latin America and suggests that the determinant of internet use (as opposed to the diffusion of internet hosts) is somehow dominated by different forces in Latin America. A 10\% rise in GDP per capita increases the number of internet users by about $13 \%\left(1.371^{*} 10 \%\right)$ while a $10 \%$ rise in lines per capita tends to increase the number of internet users by about $7 \%(.735 * 10 \%)$.

Table 7. Dependent variable: Ln internet users pc in Latin America

(first column is coefficient, second is p-value)

\begin{tabular}{|c|c|c|c|c|c|c|c|c|c|c|}
\hline & \multicolumn{2}{|l|}{1} & \multicolumn{2}{|c|}{2} & \multicolumn{2}{|c|}{3} & \multicolumn{2}{|l|}{4} & \multicolumn{2}{|c|}{5} \\
\hline & \multicolumn{4}{|c|}{ entire sample } & \multicolumn{6}{|c|}{ restricted sample } \\
\hline & & & & & & & & & & \\
\hline Lagged dependent variable & & & -1.120 & 0.570 & & & & & & \\
\hline Ln GDP pc & 1.371 & 0.008 & 1.622 & 0.053 & 0.358 & 0.687 & 0.478 & 0.324 & 0.314 & 0.573 \\
\hline Ln Costs & -0.337 & 0.360 & -0.686 & 0.377 & -0.282 & 0.477 & 0.091 & 0.775 & 0.202 & 0.610 \\
\hline Ln Lines pc & 0.735 & 0.061 & 1.432 & 0.291 & 0.033 & 0.950 & -0.912 & 0.033 & -0.728 & 0.094 \\
\hline Ln PC's pc & 0.326 & 0.571 & 1.785 & 0.489 & -0.477 & 0.327 & -1.527 & 0.047 & -1.442 & 0.093 \\
\hline $\ln$ Gini & & & & & & & -10.496 & 0.014 & -10.204 & 0.041 \\
\hline Regulation & & & & & & & & & -0.168 & 0.582 \\
\hline Regulation*privatization & & & & & & & & & 0.288 & 0.435 \\
\hline & & & & & & & & & & \\
\hline Obs. & 63 & & 63 & & 36 & & 36 & & 36 & \\
\hline R2 & .979 & & .941 & & .984 & & .992 & & 0.992 & \\
\hline
\end{tabular}

All specifications control for additive year and country effects

Second, internet costs become somewhat more significant when compared to the determinants usage in the world - although not enough to be able to consider it to be a clear determinant factor. Again, the results are sensitive to the introduction of specific controls. As above in Table 5, we restrict our sample to those countries with information on inequality and institutional variables. Overall, our sample size falls from 63 observations to 36 observations. A comparison of columns 3 and 1 should make us wary of the possibility of extending the results for the restricted sample to the whole of Latin America. The coefficients change significantly suggesting that the restricted sample might be non-randomly selected in terms of users per capita. Again, however, inequality enters significantly with a negative sign suggesting that a $10 \%$ rise in the Gini halves internet diffusion. As before, it is difficult to find any independent effect for privatization and regulation. Lines per capita now enter with a negative sign but we cannot reject the hypothesis that its coefficient is statistically undistinguishable from zero at $5 \%$ significance level. 


\section{WHAT ARE THE REGULATORY POLICY IMPLICATIONS?}

Both the stylized facts and the econometric results suggest three clear concerns with policy implications:

- Affordability matters as revealed by the systematically significant sign of GDP/capita and the overall relevance of internet access costs;

- Access to basic telecom services matters as indicated by the systematic relevance of the number of fixed digital lines per capita;

- Access to basic connection infrastructure matters as indicated by the relevance of number of PCs per capita.

The third concern fits into what some would label industrial policy. The evidence reviewed shows that PC penetration in the region continues to be low and is a major inhibitor to internet penetration. Mass market computers (below $\$ 1,000$ ) are not that readily available as a result of continued import barriers and high transport costs. Decisions as to how to increase the number of PCs per capita have implications for many types of policies and their discussion goes beyond the scope of this paper. The first two concerns however can be addressed by rather well-defined regulatory policies and fit into the unfinished reform agenda mentioned earlier. ${ }^{21}$ Access costs in regulated activities are driven by regulatory guidelines, confirming the importance of the outstanding regulatory agenda. 22 More specifically, access and affordability must be addressed jointly by the design of regulation to ensure that the expansion of the internet usage in the region follows an expansion of the access to telecoms services. This will require a higher phone penetration and a much better integration of the old fixed networks with the new communications tools. The main specific concerns regulators should have in addressing these issues is the focus of the rest of this section. We first review the basic technical and economic features of a communication network, next we tackle the access issue and finally conclude with affordability.

\footnotetext{
21 Remember we are not addressing the issues relating to e-commerce which raise many other regulatory issues. 22 Wallsten (2001) finds in an heterogeneous sample of African and Latin American countries that the joint effect of privatization and regulation is significant and positive on fixed network expansion; Gutierrez and Berg (2000) also find significant positive impacts of the regulatory framework on telephone lines per capita for the period covering 1985 to 1995 in a sample of 19 Latin American countries.
} 


\subsection{Telecommunications networks: a brief overview}

Telecommunications networks are made of different components that can be broadly divided into two main elements, switches and transmission. Switches allow the routing of signals throughout the network, while transmission supplies the capacity to transport the signal in various ways, including wireline transmission (copper wires, cable, optical fibre) and wireless transmission (satellite, cellular, microwave). On top of transport facilities and routing services, at a higher layer value-added services are typically provided over a network.

Telecommunications is a network industry, meaning that final products are made of interconnected components supplied at different points over the network. The interdependency at the technological level has its important counterpart at the consumer level. Subscribers want wide ranging communication devices as long as connectivity is ensured. This phenomenon is known as a network externality since each subscriber's willingness-topay for telecommunications services increases with the size of the subscriber base that can be potentially contacted. For example, suppose that each individual gains a benefit of 1 from being able to communicate with any other individual; and suppose that there are $\mathrm{N}$ individuals on the network. Then the total value of the network is the number of pairings $N(N-1)$, which is close to $\mathrm{N}^{2}$ when $\mathrm{N}$ is large. This square relationship between the number of members of a network and the value of the network is known as Metcalfe's law. There are also indirect benefits associated with a large network. The more members of the network, the more likely it is that new services will be offered over it. ${ }^{23}$

Network externalities represent a plausible justification for policies aimed at tackling the affordability problem (section 4.5). A policy of universal access can be a way of inducing "marginal" consumers to connect to the benefit of everybody when the private benefit of joining a network is lower than the social benefit that also includes the benefit conferred on existing users. It is also important to notice that network externalities have important strategic implications since larger incumbents can block entrants by denying interconnection to them.

The layered structure of a network is crucial when considering the type of competition that can be envisioned in the industry. The rewards to an operator depend on the degree of interdependence with services offered by operators at other layers. If an operator is integrated, there is less risk that connectivity is jeopardized; however this may lead to excessive market power in the final market. Moreover, this would imply that every operator can supply each required component, and this could be unrealistic or it could induce a wasteful duplication of

${ }^{23}$ See Katz and Shapiro (1985) and Farrell and Saloner $(1985,1986)$ for seminal analyses of positive network externalities. 
resources. Hence, there will be "bottleneck" facilities, in the hands of an operator, that are vital for the final provision of services offered by other operators.

In particular, the local loop represents the connection between the subscriber's premise and the end office. It is still seen as the main bottleneck in the industry and it is pivotal in the current regulatory process. The bottleneck nature can be understood by noting that the link close to the customer premise (the distribution plant) is essentially a fixed cost, in the sense that its cost is not traffic sensitive, i.e. it does not vary with the subscriber's usage. If one includes also the local switch, some elements are traffic sensitive (interfaces depend on the number of lines, etc.), however economies of scale would still be predominant. 24

\subsection{What's the access problem in theory and in practice?}

Suppose that you want to send an e-mail. For most of us, we would first access the Internet by calling an Internet Service Provider (ISP) over a telephone line. The average e-mail message is broken into around 20 pieces, or packets, by the sending computer. These packets are sent over a standard telephone line to the ISP, using a modem to convert the computer's digital information to the analog waves that telephone lines transmit. Each packet is transmitted to the nearest 'router': a special computer, dedicated to receiving and forwarding packets, that is the Internet equivalent of a telephone switch. The passes each packet onto another router, or to the destination if it is close enough. Once all the packets arrive at their destination, they are reassembled into the original e-mail and read. Of course, each user does not care about which routers have handled the individual packets in an e-mail. What matters is the joint function of all of the components. In the language of economics, the different parts of the network are called complements - items that are worth more together than separately.

All this turns into very practical issues for regulators. First of all, it is clear that interconnection should be mandated to ensure complementarity: if the various bits are not interconnected the service would not work. This means that a technical problem of compatible standards and interfaces has to be tackled. This is probably not a major problem for Latin America since the underlying technologies are in any case developed abroad and operators are mainly users rather than suppliers of new technologies. The type of intervention at this level

24 On the other hand, compared with the provision of access and local calls, long-distance telecommunications represents a comparatively favorable area for the development of competition. It is relatively straightforward for an entrant to establish a rival long distance fiber optic network, possibly utilizing an existing infrastructure, such as canals or railway lines linking major cities or high voltage transmission networks. Microwave technology can also be utilized as a stop-gap mechanism. This observation applies particularly to high volume (thick) routes, which are capable of sustaining several operators. Certain low volume (thin) routes may, however, remain effective monopolies. 
should be minimal. ${ }^{25}$ In principle, once technical interconnection is ensured, the externality problem should disappear, in the sense that if all consumers are interconnected they benefit from the network effect anyway, independently of the operator they subscribe from. Unfortunately, the picture is not quite so simple since interconnection is also an economic problem. Once a feasible interface is established, operators have to find ways of compensating other operators for the use of the latter's infrastructure.

The most obvious solution is to let the parties negotiate an interconnection agreement and this is what most regulators take as a first step, as shown in Table 8. This may actually work when there is a "double coincidence of wants" between the two interconnecting operators, i.e. when both operators have subscriber bases of comparable sizes and need each other in order to terminate calls destined to the rival's network. In Latin America, this is unlikely to be the case under the current conditions. There is typically an incumbent operator that is integrated over all the basic components of a network, facing entrants that have only parts of the infrastructure and need access to some elements of the incumbent (typically, the local loop, as we discussed in the previous section). In that case, entrants depend on the incumbent's facilities while the reverse is not true. Negotiations are then doomed to fail. As a result, the regulator or the competition agency must act as a referee. The first step for the referee is to identify costing rules ensuring that competition creates an interconnected network bringing together not only traditional telecommunications networks but also all the new Information and Communications Technologies including mobile, internet, satellite and cable TV networks.

The most common costing rule is the Long Run Incremental Cost (LRIC) as a benchmark to assess the costs that will have to be covered by interconnection rates. While many have had to come up with estimates of these costs based on international comparisons, only a few countries in Latin America are developing their capacity to actually estimate them through a formal model. Argentina and Peru are actually following the lead of the US after its own 1996 Telecoms Act which required the FCC to come up with a transparent model to assess costs. ${ }^{26}$ Colombia has a very impressive proposal to work along the same lines. The expected effects on costs are dramatic. The initial simulations for Argentina resulted in the

\footnotetext{
25 In principle, regulators could ask operators to adopt particular standards or technologies. Despite this problem is beyond the scope of this paper, it may be worth saying that standards often emerge on a commercial basis and it is questionable whether the regulator would be able to pick the best standard or technological solution in the first place. Technological neutrality while ensuring inter-operability seems the best approach to regulation.

${ }^{26}$ Benitez et al. (2001).
} 
ability of the regulator to get companies to cut connection costs from $2.35 \mathrm{cts} /$ minute to 1.1 cts/minute.

Table 8. Basic interconnection principles in a sample of countries

\begin{tabular}{|c|c|c|c|c|}
\hline & $\begin{array}{c}\text { Nature of } \\
\text { interconnection } \\
\text { charges }\end{array}$ & Pricing model & $\begin{array}{c}\text { Regulatory } \\
\text { approval of } \\
\text { charges }\end{array}$ & $\begin{array}{c}\text { Unbundling of } \\
\text { facilities or of } \\
\text { accounts }\end{array}$ \\
\hline Argentina & $\begin{array}{c}\text { Commercial } \\
\text { Agreement (CA) }\end{array}$ & LRIC & $\mathrm{Y}$ & $\mathrm{Y}$ \\
\hline Bolivia & $\begin{array}{c}\text { Imposed by regulator } \\
\text { (IR) + CA }\end{array}$ & LRIC & $\mathrm{N}$ & $\mathrm{N}$ \\
\hline Brazil & CA & & $\mathrm{N}$ & \\
\hline Chile & IR & LRIC & $\mathrm{Y}$ & $\mathrm{N}$ \\
\hline Colombia & IR & LRIC + FDC & $\mathrm{Y}$ & $\mathrm{Y}$ \\
\hline Costa Rica & IR & OPPORTUNITY & $\mathrm{Y}$ & $\mathrm{N}$ \\
\hline El Salvador & $\mathrm{CA}$ & LRIC & $\mathrm{N}$ & $\mathrm{Y}$ \\
\hline Jamaica & $\mathrm{CA}$ & NONE & $\mathrm{N}$ & $\mathrm{N}$ \\
\hline México & $\mathrm{CA}$ & LRIC & $\mathrm{N}$ & $\mathrm{Y}$ \\
\hline Panama & $\mathrm{CA}$ & LRIC & $\mathrm{N}$ & $\mathrm{Y}$ \\
\hline Peru & IR working as a cap & LRIC & $\mathrm{Y}$ & $\mathrm{Y}$ \\
\hline
\end{tabular}

Source: ITU

Since so many in the region are working on the implementation of a similar model, it may be worth reviewing what theory has to suggest on its benefits and its potential limitations. LRIC is a measure of the true economic cost of an asset and sends the right makeor-buy signal to alternative suppliers of infrastructure. It is a long run measure of costs and does not overestimate the value of assets as it would be most likely done if one adopted historic costs. This is quite important for countries with a long tradition of accounting systems distorted by inflation as in Latin America. Capital is included in its measure (depreciation is rightly considered as an economic cost), allowing potentially for full recovery. In fact, if a new technology were more efficient than an existing one in a competitive market with free entry, then entry would occur and prices would have to equal LRIC. LRIC should represent the long run equilibrium level of charges, hence it guarantees to achieve allocative efficiency. Although the details are quite complicated, the underlying principles for its computation are the following:

- Assets are valued and depreciated on a current cost account basis, giving the current replacement cost of a modern efficient asset;

- Operating capital costs are grouped together according to the cost type and cost driver; 
- Cost-volume relationships are estimated showing how these costs change over the long run with volumes of the relevant cost-driver;

- Increments are defined and the model determines how much the volume of a cost-driver falls if an increment is no longer provided. The cost-volume relationships then show the cost saving. 27

It is important to mention the shortcomings of LRIC when badly calculated. Firstly, LRIC is at odds with traditional depreciation practices (typically straight-line). In the presence of technological progress, straight-line schedules would underestimate the true economic annual cost. Slow depreciation schedules may be attractive to regulators who can then obtain lower current prices and hence encourage entry. However, this does not have any economic justification and it is also sustainable only if the regulator could promise at the same time higher future prices, otherwise investments would never happen. Secondly, the computation of LRIC is for an activity which is an input to the production of two or more outputs, quite a common feature in telecommunications (think of exchange switches). The definition of increments turns out to be crucial and it is often dictated by objectives other than efficiency. Thirdly, LRIC computations still involve a lot of discretion, in particular in the definition of a sensible cost of capital in countries with a high degree of uncertainty to be reflected in the minimum rates of return required to get the investors to make the necessary investments.

The theory behind LRICs is respectable, but their calculation is another matter. In Latin America it requires a strong commitment to come up with reasonable asset valuation rules supporting the development of the model. Reconciling LRIC and common depreciation practices is quite a challenge. The very impressive proposal for the implementation of LRIC in Colombia posted on the web site of its regulators ignores this issue. LRIC also assumes the ability of the regulator to assign the various joint and common costs in a fair way while common practice ends up with arbitrary rules. This is why the case of Argentina is very interesting: the regulator decided to have a formal discussion of the actual allocation decisions with all the operators before its adoption, providing a quantifiable ground for discussion.

The calculation of the LRIC of the bottleneck facility to which all new entrants want to connect is not the end of the story. The next question to ask is how to use the LRIC estimate

\footnotetext{
${ }^{27}$ LRIC can be derived using bottom-up approaches (based on engineering estimates of the assets and operating resources needed to provide services) and top-down based on existing cost structures reported in the accounts. Bottom-up estimates are more precise in enabling cost causation for capital assets to be identified (since they are based on explicit parameters) and easy to review. But they also bring many areas for disagreement, for instance
} 
to set the access price. This is quite critical since often access prices are over half of the costs of downstream entrants. Imagine the following stylized situation. In order to provide one unit of final good, downstream firms need one unit of the upstream input that is produced by the bottleneck owner at a unit LRIC $c_{0}$ in exchange for a unit access charge denoted by $a$. If all firms in the downstream sector are similar (in terms of technology and thus of costs) and their products are identical, firms undercut each other until price competition drives to zero all extra profits. The price charged to final users ends up equal to the marginal cost of each firm, which amounts to the sum of the access charge and any other cost incurred in order to transform the intermediate good. If we denote the latter by $c$, the final price would be $p=a+$ $c$. The lower the access charge, the lower the final prices and the higher the total quantity consumed by the end-users.

Without any other source of distortion, the best that could be done is to follow a marginal rule: the price to the final user (the consumer willingness-to-pay) should be set equal to the total marginal cost of production. The access price should thus be set equal to the marginal cost of production $\left(a=c_{0}\right)$ and in the end the consumer price would be $p=c_{0}+c$. On the other hand, distortions in the incumbent's retail prices typically exist for various reasons, for instance because the bottleneck involves also some unapportioned fixed costs, hence a marginal rule would not allow to recover them. Another type of distortion arises when the incumbent's prices do not reflect its cost structure, because the incumbent is constrained by some social obligations to charge identical prices in different geographic region - more on the actual importance of social obligations in Latin America later. In these circumstances, a marginal rule is not the correct benchmark unless additional instruments are used simultaneously to relieve the access charge from additional tasks. Access charges purely based on LRIC are an appropriate benchmark when retail-level distortions are eliminated (for instance by tariff rebalancing) or dealt with using other instruments. On the other hand, the common practice to apply uniform mark ups to the LRIC estimates to recover un-apportioned costs does not reflect much economic analysis.

Table 9 summarizes the main options for access pricing under different situations. ${ }^{28} \mathrm{~A}$ quick glance suggests that the rather complex theoretical contributions deliver one message: the access charge is often performing too many tasks. The main interest of the table is that it makes the point that different goals and policy objectives lead to alternative ways of

on the definition of "appropriate" equipment. In contrast, top-down approaches can reflect complex networks and do not omit costs. Their downside is that they are more opaque, hence they may hide inefficiencies.

${ }^{28}$ For more details, see the surveys by Armstrong (2001a) and by Valletti and Estache (1999). 
calculating optimal charges. While it is true that theory is extremely useful to understand the mediating function of access prices, we stress that one first fundamental step should precede any access distortion: whenever possible, the use of access pricing as an instrument for the promotion of too many goals should be resisted and other instruments should be used.

Table 9. How to set an access charge: what the theory says

\begin{tabular}{|c|c|c|c|}
\hline Basic case & $\begin{array}{l}\text { Access } \\
\text { charge: }\end{array}$ & Potential problems: & $\begin{array}{l}\text { Eventual remedies (with best practice } \\
\text { examples): }\end{array}$ \\
\hline First best & LRIC & May require lump sums & $\begin{array}{l}\text { - } \quad \text { tariff rebalancing (Dominican Republic) } \\
\text { - USO funds (Chile or Peru) }\end{array}$ \\
\hline Second best & Ramsey (1) & $\begin{array}{l}\text { - informational content } \\
\text { - may not be sustainable }\end{array}$ & $\begin{array}{l}\text { - Global price cap (under study in Costa } \\
\text { Rica, Mexico, Peru ) }\end{array}$ \\
\hline Productive efficiency & $\operatorname{ECPR}(2)$ & partial rule & \\
\hline \multicolumn{4}{|l|}{ Extensions: } \\
\hline $\begin{array}{l}\text { Entry promotion for: } \\
\text { - Product variety } \\
\text { - Entry barriers } \\
\text { - Learning-by-doing }\end{array}$ & Decrease & $\begin{array}{l}\text { fixed cost may not be } \\
\text { recovered }\end{array}$ & $\begin{array}{l}\text { direct explicit or implicit subsidies } \\
\text { (through differentiated treatment of } \\
\text { incumbent and new entrants as in Brazil, } \\
\text { and maybe soon in Ecuador, Honduras) } \\
\text { equal access }\end{array}$ \\
\hline $\begin{array}{l}\text { - By pass } \\
\text { - Cost duplication }\end{array}$ & Increase & $\begin{array}{l}\text { small entrants } \\
\text { disadvantaged }\end{array}$ & - Quantity discounts \\
\hline Market power & Decrease & $\begin{array}{l}\text { fixed costs may not be } \\
\text { recovered }\end{array}$ & $\begin{array}{l}\text { - } \\
\text { - competice regulation policy (Argentina, Brazil and } \\
\text { Mexico may be the most typical examples } \\
\text { of an effective coordination between the } \\
\text { competition agency and the telecoms } \\
\text { regulator) }\end{array}$ \\
\hline
\end{tabular}

Notes: (l) Ramsey prices are inversely related to the elasticity of demand and apply both to final and intermediate services. They are "second best" in the sense that they are the best that the regulator could do when it cannot repay the incumbent's fixed costs via lump sums, hence'the wholesale and retail prices alone should recover the incumbent's costs. Ramsey charges are a good theoretical benchmark that says that markets are related so that demand and supply cannot be considered in isolation. They can be put in practice via global caps that put a limit to the overall price of a basket of services (both retail and wholesale), while the operator is left with the flexibility to set individual prices within the basket. ${ }^{29}$

(2) ECPR (Efficient Component Pricing Rule) states that the access charge should be set equal to the direct cost of supplying access plus the opportunity cost represented by the forgone profits of the incumbent when it is displaced by an access seeker. This is equal to the difference between the retail price and the cost of the competitive segment. ECPR willingly narrows its considerations on the allocation of production between the bottleneck proprietor and its rivals. On the theoretical side, it introduces the powerful concept of opportunity costs. On the practical side, ECPR is a rather simple rule guaranteeing that only efficient entrants are granted access. It gives valid guidelines if there is no problem of recovery of fixed costs and static productive efficiency remains the only goal. On the other hand, if not conjoined with complementary instruments (such as final price regulation, or price floors and ceilings), ECPR allows monopoly rents and anti-competitive conduct.

29 See Laffont and Tirole (2000). 
Regulators should be aware that there is a sequencing of events that can reduce the complexity of the access problem. For instance, if the regulator believes there are barriers to entry, the tax/subsidy issue of the entry barrier should be addressed directly and be made explicit, rather than burying it into the access pricing problem. The latter could indeed be the only option available, but only after having realized that other options are not feasible. A similar argument can be made for universal service obligations as discussed later. In other words, by understanding the links between different problems, new instruments become available that allow fine-tuning of the regulatory process.

Table 9 also deals with situations in which access prices should be decreased compared to benchmarks in order to promote entry. Again, the first question has to be why entry should be promoted. If this is because entry brings benefits from product variety but there are barriers to entry, a simultaneous effort should be made to remove them. This can be done by mandating equal access for instance and this is the solution that has been adopted in Peru and Venezuela where the law (in Peru) and the interconnection regulation (in Venezuela) explicitly states that all interconnection agreements must reflect the principles of neutrality, non discrimination and equal access.

The consensus approach to coming up with reasonable estimates of the access charges adopted by Argentina is quite instructive. From the viewpoint of market liberalization, since 1998, Argentina has made most of the right moves. Argentina has opened the market, allowed the resale of services and now considers all operators to be service providers. The local network has been unbundled. Interconnection has been set at incremental cost. Argentina has also adopted minimum subsidy auctions for the yet unserved areas. There are many outstanding issues but the model is well under way to be one of the most pro-market in the region and may be a leading indicator of things to come. Since 1998, the regulators have recognized that details matter and that the implementation of many of the decisions required some analytical support. In that context, the telecoms regulator financed the estimation of a cost model for telecommunications as a research project with the support of a research grant from the World Bank and from the main incumbent telecoms companies concerned with difficulties on access issues in preparation for the announced liberalization of the market. The research project brought together some of the top foreign academics in the field of regulation and in particular access pricing (Jean-Jacques Laffont and Bill Sharkey were involved in identifying some of the key issues in conversations with all the key players (operators and regulator)). The author of an equivalent model developed for the U.S. was recruited to train a team of young local researchers who developed the local model with his help. 
The process of model development may in fact have been one of the most useful aspects of this experience. Argentina now has a cost model which has been used to assess LRIC in the context of universal service obligations and, had it not been for the recent crisis, it should now have made a lot more progress on the access issue as well. In the mean time, Argentina is like many other countries working with benchmarks, but many of the actors in the sector are hoping that once the macro situation is stabilized, the micro issue will again get the attention it deserves from the key policymakers. Good regulation requires some initial investment which is too often one of the first to be frozen under economic crisis situations.

\subsection{How to address the access problem when investment is needed?}

The second component of the regulatory challenge is the need to encourage investment. There is a trade off between optimal access regulation in a static framework and in a dynamic one. If static regulation reduces the use of monopoly power over the infrastructure, then it also reduces profits that can be earned by the investor/owner of the facility. Access regulation setting interconnection rates based on simple cost recovery rules, while encouraging efficient utilization of assets, may risk discouraging investments. The reason is simple. If operators rationally anticipate that, once somebody has invested, then the regulator will grant access at cost, everybody will then wait for the investment to be done by somebody else and then seek access.

This is a typical free rider problem that may cause big losses in social welfare. At best, investments are reduced; in the limit there may even be no production at all if no one invests in infrastructure. ${ }^{30}$ At the same time, the regulator should promote the legitimate objective to have a downstream level playing fields.

Imagine the typical environment for telecoms operators in Latin America, in which a network has to be built and the investment cost declines over time due to technological progress, and in which operators are left to bargain first to settle interconnection charges. Incumbent operators must first decide whether and when to invest knowing that their

\footnotetext{
30 There is an obvious parallel between this problem and the kind of public policy that may best encourage innovative activities and the dissemination of Research \& Development (R\&D) efforts. On the one hand, once one individual firm has acquired knowledge about a new product or a new way to produce something, it is virtually costless to share this information with others. Hence the firm that has made the discovery should share it with others, and should compensate only the long-run marginal costs. On the other hand, it is clear that such a scheme would seriously erode any incentive to pursue any innovative activity in the first place. The question of how to best balance the aim of encouraging innovative activity by protecting intellectual property against the aim of promoting the competition that such protection inhibits has been an enduring tension in policy debates. The empirical evidence is far from uniform, but one general finding seems to be robust and relevant to the telecom investment issue: $R \& D$ intensity appears to increase in industrial concentration but only up to a certain value, after which R\&D efforts appear to level off or even decline.
} 
exclusivity period has or will soon end and that there are rivals deciding whether and when to seek access. A major element in the bargaining game between the two parties is the specific design of the access rules defined by the regulator.

One could think that if operators offer sufficiently differentiated products, there should not be any particular concern since the use of the investment is non-rival and infrastructure owners do not fear the rent dissipation caused by downstream competition and thus have an incentive to optimize the use of the facility. This conjecture is not true. Negotiations can only be over variables that can be altered at the time of negotiation. As the investment has already taken place, infrastructures themselves are sunk and cannot play a role during negotiations. Thus the provider has a weak position. By denying the rival the use of the infrastructure, it gains nothing and loses whatever access charge it might receive. The operator ends up with a weaker incentive to invest even if products are differentiated. ${ }^{31}$

There is also another aspect that crucially could affect the scenario which the regulator can use. The access seeker may be trying to become the provider itself and start selling access to its rival. In this case negotiations would be reversed. There is a potential for both firms to "race" in order to be the first to provide the infrastructure. By doing so, an operator avoids the access payments and receives access payments. This gives a reason to pre-empt rivals and incentives to invest are then raised. The race to become the "common carrier" speeds up the operators' choices.

Access issues become of greater concern when firms that use the infrastructure are also direct competitors of the infrastructure owner as is so often the case in Latin America. If competition effects are extreme, the infrastructure owner will not grant access unless required to. Here regulation plays a stronger role. The entrant is obviously keen on obtaining access. Without compensation, however, the incumbent will wish to delay investments. This can be solved by requiring the entrant to bear more of the costs. But for the regulator this increase might reduce the possibility of entry itself. The regulator should try to manage this tension between investment incentives and timely competition.

The point that we are making here is that an access price régime can be used by the regulator to create competition between industry participants over the provision of facilities. If a firm "wins" in the provision of infrastructure, it becomes the common provider and receives access payments from other firms. If it loses, it will either pay for access or duplicate the

31 What we have just described here is a typical hold up problem due to contract incompleteness. 
infrastructure. By committing to an appropriate access rule, the regulator can directly determine the difference between winning and losing for operators.

The existing theoretical literature has not come up yet with a general answer to this intricate problem. The possible trade off between static and dynamic efficiency that we highlighted at the beginning of this section should not be taken as the only possibility since regulation interacts with other important variables such as market structure and entry conditions, competitive behavior of market participants, and technological progress. For instance, the unintended outcome of bad regulation could be to achieve low levels of both static and dynamic efficiency. This could be the situation in mobile telephony if too little spectrum is made available to a handful of companies that do not compete against each other and do not need to adopt innovative technologies if they are protected against entry by licence conditions. Conversely, under some circumstance it is possible to achieve the best of the possible worlds, i.e. high levels of both static and dynamic efficiency. In this situation operators would be competing against each other, achieving relatively efficient allocations, while still securing profits that create the incentive to invest. The presence of strong network externalities can support a case like this one.

Only after unraveling the linkages between entry, investment, competition, and regulation could the regulator understand the pros and cons of basic modes of entry and eventually promote a particular one. The two main ones are facility-based competition (FBC) and service-based competition. In telecommunications, local loop unbundling (LLU) is a special form of service-based competition that is particularly important in the current debate. Under FBC both the incumbent and the entrant build their own backbones and local loop facilities. Customers can in principle subscribe directly to both operators. The only relevant access price is related to call termination on the rival's network. Contrary to the previous case, under LLU the entrant leases the incumbent's access facilities. On top of call termination, regulatory oversight should include the line rental that the incumbent receives from the entrant.

While the actual answer to the question FBC vs. LLU would need to be calibrated case by case, we can highlight the main trade-offs clarified by economic theory:

- If investments are to be promoted, there is a potential trade-off between ex post extraction of rents and ex ante incentives to invest.

- FBC may involve unnecessary duplication of infrastructure, and in this respect LLU should be preferred.

- However, FBC is beneficial when it brings about higher speed, less congestion and product complementarities. 
- LLU gives the regulator additional regulatory instruments. The downside is that regulation also becomes much more intrusive. Hence, FBC has the additional benefit that the regulator can rely more on direct competition than on regulatory intervention.

- Flexibility should be allowed in different respects. The regulator should offer a menu of options designed in a way such that particular entry modes are promoted. Operators should be allowed some flexibility to set their access charges subject to constraints on their overall level.

\subsection{Summary tips on the choice of a regulatory policy for access}

This is probably one of most complex issues in the area of telecoms regulation and there are many aspects we have not touched on. ${ }^{32}$ But the.preceding quick overview of theory and practice allows the following conjectures about the key factors which should influence the choice of a regulatory policy. Firstly, regulation can elicit excessive investment or, conversely may kill most investment opportunities. The latter is more likely than the former in Latin America. This might happen, for example, if access prices were prohibitively high, leading either to the perpetuation of a monopoly. Secondly, willingness to invest is likely to be influenced by the perceived risk of investment. There is thus value in either establishing a set of (possibly changing) access pricing rules in advance, or - at least - a commitment by the regulator to criteria set in advance. Thirdly, the interaction between retail prices and the structure of access prices will have a major impact on incentives to invest in different parts of the telecommunications network. Rebalancing the tariff will eliminate some distortions, but continuing geographical averaging will also limit the location of investment. Finally, flexibility should be encouraged, in terms of both allowing entrants to choose from a "menu" of entry modes with possibly differentiated structures of access charges, and incumbents to set different charges subject to average constraints.

How can the access pricing debate be put into practice? It is quite obvious to say that regulators should try to employ more sophisticated economic tools and engineering methods to come up with a structured framework that allows to use in an appropriate way engineering

\footnotetext{
32 For instance, one may argue that once facility-based competition is mature, foreclosure is not a great danger since operators would have an incentive to conclude successfully commercial negotiations over the interconnection terms. This is probably true, however some regulatory scrutiny would still be needed to restrain various forms of anti-competitive behavior. For instance, an operator may be competing for customers but, once it has secured some of them, it has effectively a monopoly power over the calls destined to them (this problem is clearly seen in the context of fixed-to-mobile calls). Even when operators are competing fiercely both over termination and origination of calls, they can still use access prices as an instrument of tacit collusion. Collusive (i.e., monopoly) prices can in fact be sustained using high access charges because of a raise-each-other's cost effect. (Armstrong, 2001a; Laffont and Tirole, 2000).
} 
estimates of costs. While this should be the aim of all regulators at least in the medium term, one should also be realistic and ask what they could do in the initial phases when such tools and methods are not available yet. The first thing that regulators should do is to remove most entry barriers, such as exclusivity periods. Entry in many cases will alleviate the regulator's problem to control retail prices. In some areas (such as densely populated areas or business districts), the regulator's problem may actually disappear since customers may have the possibility to choose among competing access providers. However, we argued before that this is unlikely and regulation of bottlenecks is quintessential in telecoms.

Entry will actually exacerbate the access problem since all entrants will have to rely to some extent on the incumbent's network. Hence the regulator should first ensure that interconnection is feasible. But at what price? If no information is available at all, the regulator can follow only two routes. It could either look at international benchmarks and set charges similar to those adopted under similar conditions elsewhere, or set a discount on the incumbent's retail prices, along the lines of ECPR. ${ }^{33}$ Both approaches are not very satisfactory but there not much more the regulator could do if it has no other information at its disposal. Benchmarks are not very good since they would be based on computations valid for countries with very different economic conditions. ECPR would have limits since it would "freeze" the structure of prices which could be inefficient if rebalancing had not yet occurred and it would oblige entrants to replicate more or less the incumbent's prices making them not very aggressive. Given that these options would be the only ones available for the regulator precisely when it is quite weak in its infant phase, it is perhaps advisable to rely anyway on international benchmarks since they are much less prone to lobbying from the incumbent. In any case, this phase should be as short as possible. The regulator should try to adopt engineering models, both to come up with reasonable figured and - more importantly - to set a ground for discussion.

When estimates become available, then the economic analysis we discussed above should be put into practice. Tariff rebalancing, access charges, service obligations are all intertwined aspects of the same general problem. In this respect, it is perhaps important to stress that an eventual engineering model would never be a machine that gives the "right" number when needed. On the contrary, it would only set an appropriate order of magnitude; besides this the regulator should try to decentralize decisions. For instance, the regulator should try to set some price cap mechanism on access charges and ask the incumbent to reduce them on

33 ECPR requires only to compute the cost of the competitive segment rather than the bottleneck's cost which is much more difficult to compute. 
average by some percentage every year, reflecting the underlying technological progress. In this respect, the regulator should avoid to "crunch" numbers from the engineering model too often, otherwise regulation would become extremely intrusive and the incumbent will never have an incentive to adopt cost-reducing technologies which, in the end, would bring prices down. Of course, there is also the risk that if the regulator does not scrutinize the incumbent's behavior, competition could be jeopardized. In this respect, while in principle it would be ideal that the regulator is also able to monitor anti-competitive behavior, in practice this should not be a priority to the extent to which the regulator learns to co-operate with the competition agency of the same country.

\subsection{The affordability problem}

The concern for affordability is quite strong among policymakers and is resulting in efforts to get tariffs in line with international trends. The first issue is that the main vehicle to the internet continues to be through phone lines and that flat rate access to local calls are not standard practice as in the U.S.. Countries are working on this. In Argentina, for instance, the creation of special internet price schemes, combined with the reduction in the cost of leased lines have significantly contributed to the diffusion of the internet. Similar initiatives can be found in the region but while they contribute to make the "haves" better, they do not necessarily do much for the "haves not". Indeed, again in Argentina, the special local connection number for internet users was initially not available throughout the country and imposed additional long distance charges to many provincial users. And, of course, this is assuming that telecom penetration is sufficient in the provinces but this is not the case. Ultimately, this is another indicator that in the rush to close the digital gap, the concern for basic failures in the implementation of the telecoms reform contributes to the digital divide. The policy implication is simple once more: come up with a policy instrument that get phone lines where there are none.

The main instrument that has been used by regulators to address the affordable access issue has been to impose universal service obligations (USOs) to operators. Table 10 summarizes Latin America's experience with USOs. According to the ITU regulatory data base, over $70 \%$ of the countries of the region include basic telephony in their definition of universal services and about a third have now added electronic mail as well. Even if the table suggests that general principles behind USOs are agreed, the differences in approaches and definitions across countries suggest implementation challenges. There are three aspects to this. 
First, what exactly should be provided and to whom? Secondly, who should be required to fulfill a USO? Thirdly, who should pay for the costs of a USO.

The exact definition of universal service varies from country to country. The most commonly used version refers to achieving a "minimum quality level" of a "basic package" of services to all consumers and at "affordable prices". In general, each part of the specific statements are open to interpretation - what is a minimum quality level, what constitutes a basic package, what prices are affordable? Some countries list a set of services and quality levels that are included in universal service (e.g., voice-grade access to the public switched network, touch-tone, etc.), and detailed maximum prices that can be charged for specific services, and on average across all services. This exercise is, of course, problematic. Technological progress means that the set of basic services is constantly expanding, and minimum quality levels are ambiguous (for example, wireless services allow greater mobility, but typically have lower sound quality and completion rates).

In spite of their popularity and their very practical relevance, USOs are under increasing pressure in the more academic literature and the reasons why should be interesting for regulators. The first source of pressure appears to be political, but actually has solid economics to back it up. A major problem with USOs is that they are blunt. A USO to cover high-cost rural areas at the same price as low-cost urban areas benefits high income rural consumers at the expense of low income urban consumers. More precisely, it may be inefficient to effect a particular objective - higher welfare for rural residents - through distorting the prices of particular services. This point has been made formally by Atkinson and Stiglitz (1976), who show that, under certain circumstances, the best way to redistribute income is through the taxation of income, not consumption. In their model, consumers differ in their income levels. Hence their result speaks most directly to the issue of subsidies to lowincome consumers. It is straightforward, however, to re-interpret their model in terms of lowand high-cost consumers. One of the key conditions required for this result is that low- and high-income consumers have the same relative preferences for consumption goods (i.e., the marginal rate of substitution between consumption goods is independent of income). In this case, taxing consumption - effectively what occurs when the prices of telecommunications services are altered - in order to fund universal service is unnecessarily inefficient. The better way to redistribute income (which, after all, is what a universal service subsidy does) is to tax income. To encourage people to live in high-cost rural areas, the theorem suggests that a location-specific income tax break is better than offering a telecommunications subsidy. The challenge is of course to find a location specific tax that is consistent with the social 
objectives to be addressed by the USO to begin with. When this is impossible, countries tend to have no option but to rely on a sector specific tax. The latest example is Argentina where companies are required to put $1 \%$ of their gross sales into a government run fund to provide basic phone services in areas unattractive to investors. ${ }^{34}$

The second challenge facing USOs comes from the introduction of competition. As seen earlier most Latin American telecommunications markets have been opened up to competition. This has consequences for the financing of USOs when USOs are supported by cross-subsidization. This cross-subsidization is sustainable while a single firm operates across the various markets, as was the case in the U.S. and the U.K. until the early 1980s. But when a second firm is able to operate, it will choose to enter the more profitable market-a process known as cream-skimming. This has three implications.

Firstly, the distortions in prices that the USO requires can lead to inefficient entry. When there are retail distortions due to a USO, then a retail instrument (such as a tax funded via a properly set fund) should be used. This can be done also in combination with an access charge that would be set equal to the marginal cost of access. Use of the access charge alone both to provide the right entry incentives and to correct the retail distortion is inferior. ${ }^{35}$

Secondly, the subsidy required to support the USO is higher than it is when entry cannot occur; since financing the USO is distortionary, this means that the social cost of the USO is higher. When consumers are heterogeneous, with some being high-cost and others low-cost, a USO subsidy set without regard to competition will be too low. The reason is obvious: such a subsidy assumes that the operator can earn excess profits from low-cost consumers, that can be used to finance service to high-cost consumers. Competition eliminates these profits, and so increases the required subsidy.

Finally, USOs that come in the form of a uniform pricing requirement have strategic effects that need to be recognized by regulators. Valletti et al. (2001) show that a USO affects the way in which operators compete. In particular, a uniform pricing restriction creates

\footnotetext{
34 Note that changes in the assumptions underlying the Atkinson-Stiglitz theorem will, evidently, change the result. For example, it may be that the marginal rate of substitution between consumption goods is not independent of income. Then it may be worth taxing those goods that the rich have a relative preference for and subsidizing the goods preferred (relatively) by the poor. Nevertheless, the result is important for emphasizing that USOs must be assessed carefully for their validity and not simply accepted as an all purpose instrument to address the financing of access. Gasmi et al. (2000) provide a good example on how to evaluate alternative subsidy schemes given various configurations of infrastructure costs and various degree of efficiency in the fiscal system (the latter affects the shadow cost of public funds that would have to by paid if direct subsidies are adopted).

35 See Armstrong (2001b).
} 
linkages between markets. This typically make operators less aggressive in those markets, leading to higher equilibrium prices and deadweight loss.

The tension between universal service and competition represents a considerable challenge for regulator. The case of VoP is instructive. Conflicts as those discussed for Colombia earlier are likely to grow when decisions will be made on whether VoP leads to direct competition with companies with a USO or not. The situation is likely to get even more complex as service obligations start to include competitive web based services such as electronic mail. A promising solution to resolve this tension is the use of universal service auctions, in which operators bid for a level of subsidy (competition for the market), with the market structure after the auction determined by the bids in the auction. This has been tried so far successfully in several Latin American countries to increase phone penetration in rural areas.

To give an example, in Chile there have been successful experiences with the use of minimum subsidy concessions to expand both electricity and public telephone services to rural communities since 1994. This is how it works. There is competition between regional governments for central government financing, between rural communities to have their project sponsored by the regional government, and between utility companies to win the concession to serve a particular rural community. Concessions are awarded to the company offering the largest reduction to the maximum allowable subsidy stipulated for each contract. Service expansion is co-financed by the state, the private sector and the rural consumer. State contributions are justified by the fact that the projects identified have positive social returns but negative private returns. Indeed, it is this differential which defines the maximum allowable subsidy. However, a substantial part of the investment costs are financed by the private operator. The average proportion for telecommunications was $72 \%$ during the period 1995-97. Customers must pay regulated service charges to cover the unsubsidized costs. Concessionaires are free to choose the appropriate technology. Although the government makes certain assumptions about technology choice in computing the maximum allowable subsidy, the winning bidder is free to select his own technological solution. The results of the programs have been encouraging. About 80 percent of the rural population now has access to a public telephone. This progress was achieved at a cost of $\$ 2,300$ per public telephone. Unit costs have risen over the life of the programs, probably because later projects have been targeted towards more isolated, and hence more costly, communities. ${ }^{36}$

36 See Estache, Foster and Wodon (2001) for more details and additional references 
To conclude this section, we summarize the most important problems related to the affordability problem. The first message to remember that Universal Service Obligations are justified on efficiency grounds even if it is debatable if they are also called for on equity grounds, since there may be better tools to achieve redistribution. On the efficiency side, there justification stems also from the fact that they can reduce the risk that customers may not subscribe to a network since they do not take into account the benefit they confer on existing users. Even if the marginal consumer confers a small externality, this has to be multiplied by large numbers. However, it has to be clear that there are also limits to this kind of justification for subsidies. In particular, subsidies should be at the margin and it is not necessary to subsidize the majority of infra-marginal customers that would be on the network without any inducement. In this respect, targeted programs fare much better that uniform subsidies. There also seem to be room for the introduction of more optional tariffs for local services. A "menu" of contracts, designed having in mind the need of the poor and of the low users, could be designed at a low cost in order to induce more people to subscribe without having to subsidize the large majority of the population. There is no reason to subsidize or maintain artificially distorted tariff structures in the belief that this is the only way to increase the subscriber base. As said above, affordability should be interpreted as affordability among an incremental group of users who are considering taking up or dropping the service.

On the more practical side, the experience of the 90 s has clearly shown that regulators should play carefully with USOs since they tend to be used by incumbents to extract too many concessions. Countries should distinguish clearly between universal availability and universal service guarantees. The former is promoted by encouraging investments and removing entry barriers. Only the latter should be explicitly linked to possible costing and financing requirements.The approach should be technologically neutral, enabling wireline and wireless technologies to be used to provide services. Setting a rigid requirement for the functionality of Internet access within the defined universal service package would prevent mobile services from fulfilling the universal service criteria. It is important to maintain incentives for competing networks and/or technologies to provide (part of) the universal service provisions.

A final point to remember is that there are many ways of ensuring that costs are kept at a reasonable level. Using auctions to assign USOs will help and the regulator does not need to calculate net costing. There are also problems. It may be difficult to have sufficient participants bidding against the incumbent (in many cases entrants would need to use alternative infrastructure or acquire the use of the incumbent's assets). Another reason is the asymmetry of information between the incumbents and new entrants, for example concerning 
the costs and benefits of serving groups of customers. If an auction is not feasible, then the regulator must calculate the net cost and then proceed to financing requirements. Financing these costs imposes distortions and regulators should try to minimize losses of allocative efficiency. The least distortionary way to finance net costs is probably from the government central budgets. Alternatively, funding should be recovered within the sector, raising a tax from the broadest possible base, in order to minimize the impact of the financial burden falling on end-users. The answer to this depends to a great extent on the efficiency of the tax system.

\section{CONCLUDING COMMENTS}

This paper has shown that an effective implementation of the regulatory agenda of telecom reform can indeed accelerate the adoption of the internet - even if it is only part of the solution since income levels, income distributions and access to primary infrastructure are the main determinants of the growth in connection and use of the internet. Regulation will work by cutting costs. Cost cutting will require the regulators in the region to take a much closer look at the design of interconnection rules and at the trade-offs that emerge from a recognition of the complexity of the issue. It also requires a commitment to develop analytical instruments to sort out many of the issues and to generate benchmarks much more consistent with the local issues and with the local cost of capital than international benchmarks will ever be for countries in unstable macro situations. It will require an equally strong commitment to impose regulatory accounting systems that reduce the information asymmetries which are used by incumbents to reduce the risks of entry. It will finally require a stronger commitment of competition agencies since in many countries, the failure of negotiating interconnection agreements will raise competition issues just as often as they will raise regulatory issues.

There are many other outstanding issues we have not really addressed in the policy part of the paper because there they deal with some supranational aspects of the management of the sector. In 1999 for instance the fact that Argentinean internet users were paying twice what Brazilian users were paying was mostly related to the cost of leased lines. While the

price of leased lines is often still controlled by an historical incumbent or its successor with strong exclusivity rights who runs both national and international connections, national competition and appropriate regulation are unlikely to be able to address that problem alone. Also, the high cost for non-US ISPs to connect to US Internet backbones with a pricing 
essentially designed to get the rest of the world to subsidize the US use of the Internet is not a local issue.

In fine, it is going to be a while until regulation manages to do what it is supposed to do. It will require national and international commitments and much more analytical work to turn laws, decrees and rules into practical instruments with the expected impact on competition and on costs. The scary part is that a demand for new laws and new regulation is already emerging with the information revolution well before the first wave of legal instruments have been fully enforced. The full success of reforms and its fair distribution among all segments of the population will require much more blood, sweat and tears from regulators than these have been willing to give so far.

\section{REFERENCES}

Armstrong, M. (2001a), "The Theory of Access Pricing and Interconnection," in M. Cave, S. Majumdar and I. Vogelsang (eds.), Handbook of Telecommunications Economics, Elsevier Science, North-Holland, Amsterdam.

Armstrong, M. (2001b), "Access Pricing, Bypass and Universal Service”, American Economic Review Papers and Proceedings 91(2): 297-301.

Atkinson, A.B. and J. Stiglitz (1976), "The Design of Tax Structure: Direct and Indirect Taxation", Journal of Public Economics 6: 55-75.

Benitez, D., A. Estache, M. Kennet and C. Ruzzier (2001), "The Potential Role of Economic Cost Models in the Regulation of Telecommunications in Developing Countries", Information Economics and Policy, forthcoming

Chisari, O., A. Estache and C. Romero (1999), "Winners and Losers from Privatization and Regulation of Utilities: Lessons From a General Equilibrium Model of Argentina," World Bank Economic Review 13(2): 357-78.

Estache, A., A. Gomez-Lobo and D. Leipziger (2001), "Utilities Privatization and the Poor: Lesson and Evidence from Latin America," World Development 29(7): 1179-98.

Estache A., V. Foster and Q. Wodon (2001), "Accounting for Poverty in Infrastructure Reform: Learning from Latin America's Experience," World Bank Institute Studies in Development (forthcoming).

Farrell, J. and G. Saloner (1985), "Standardization, Compatibility, and Innovation," RAND Journal of Economics 16: 70-83. 
Farrell, J. and G. Saloner (1986), "Installed Base and Compatibility: Innovation, Product Preannouncements, and Predation," American Economic Review 76: 940-955.

Gasmi, F., J.-J. Laffont and W. Sharkey (2000), "Competition, universal service and telecommunications policy in developing countries," Information Economics and Folicy 12(3): 221-48.

Gutierrez, L. and S. Berg (2000), "Telecommunications liberalization and regulatory governance: lessons from Latin America," Telecommunications Policy 24: 865-884.

Katz, M.L. and C. Shapiro (1985), "Network Externalities, Competition, and Compatibility," American Economic Review 75(3): 424-40.

Keler, W. (2001), "International technology Diffusion", NBER Working Paper No. 8573, October

Kiiski, S. and M. Pohjola (2001), "Cross Country Diffusion of the Internet," United Nations, WIDER Discussion paper 11/2001.

Laffont, J.-J. and J. Tirole (2000), Competition in Telecommunications, MIT Press, Cambridge (MA).

Levy, B. and P.T. Spiller (1994), "The Institutional Foundations of Regulatory Commitment: A Comparative Analysis of Five Country Studies of Telecommunications Regulation", Journal of Law, Economics and Organization, Vol. 10, $\mathrm{N}^{\circ} 2$.

Levy, B. and P.T. Spiller (1995), The Institutional Foundations of Regulatory Commitment, Cambridge University Press, New York

Levy, B. and P.T. Spiller (1996), Regulations, Institutions, and Commitment: Comparative Studies of Telecommunications, Cambridge U Press, New York

Norris, P (2000), "The Global Divide: Information Poverty and Internet Access Worldwide", available at http://www.ksg.harvard.edu/people/pnorris/acrobat/IPSA2000.pdf.

Rodriguez, F. and E. Wilson III (2000), "Are poor countries losing the information revolution", The World Bank, infoDev Working Paper, available at http://www.infodev.org/library/working.htm.

Röller, L.H. and L. Waverman (2001), "Telecommunications Infrastructure and Economic Development: A Simultaneous Approach", The American Economic Review 91(4): 909-923.

Stoneman, P. (ed.) (1995), Handbook of the Economics of Innovation and Technological Change, Blackwell, Oxford.

Valletti, T.M. and A. Estache (1999), "The Theory of Access Pricing: An Overview for Infrastructure Regulators," Policy Research Working Paper 2097, The World Bank. 
Valletti, T.M., S. Hoernig and P.P. Barros (2001), "Universal Service and Entry: The Role of Uniform Pricing and Coverage Constraints," Journal of Regulatory Economics (forthcoming).

Wallsten, S. (2001), “An Econometric Analysis of Telecom Competition, Privatization and Regulation in Africa and Latin America," Journal of Industrial Economics 49(1): 1-19. 
Table 1: Summary of key reforms elements in Latin America's telecoms sector

\begin{tabular}{|c|c|c|c|c|c|c|c|c|c|c|c|}
\hline & \multirow{2}{*}{$\begin{array}{l}\text { Key reform } \\
\text { law for } \\
\text { telecoms }\end{array}$} & \multirow{2}{*}{$\begin{array}{l}\text { Year of first } \\
\text { incumbent } \\
\text { privatization } \\
\text { action }\end{array}$} & \multirow{2}{*}{$\begin{array}{l}\text { Degree of } \\
\text { privatization of } \\
\text { incumbent } \\
\text { operator }\end{array}$} & \multirow{2}{*}{$\begin{array}{l}\text { Period of exclusivity } \\
\text { for initial new } \\
\text { incumbent } \\
\text { (begins-ends) }\end{array}$} & \multicolumn{3}{|c|}{$\begin{array}{l}\text { Level of competition } \\
\text { (as of early 2000) }\end{array}$} & \multirow{2}{*}{$\begin{array}{l}\text { Effective } \\
\text { creation of } \\
\text { regulatory } \\
\text { agency }\end{array}$} & \multirow[t]{2}{*}{$\begin{array}{l}\text { Telecoms } \\
\text { specific }\end{array}$} & \multirow[t]{2}{*}{ Regulator financing } & \multirow[t]{2}{*}{$\begin{array}{l}\text { Regulator } \\
\text { reports to: }\end{array}$} \\
\hline & & & & & Local & $\begin{array}{l}\text { Long } \\
\text { distance }\end{array}$ & $\begin{array}{l}\text { Digital } \\
\text { cellular }\end{array}$ & & & & \\
\hline Argentina & 1989 & 1990 & Full & $1990-2000$ & $\mathbf{P}$ & $\mathbf{P}$ & $\mathbf{P}$ & 1990 & $\bar{Y}$ & Regulatory fee & Ministry \\
\hline Bahamas & 1992 & Delayed & & & $\mathbf{M}$ & $\mathbf{M}$ & $\mathbf{M}$ & 1993 & $\mathbf{N}$ & $\begin{array}{l}\text { Government budget }+ \\
\text { auction revenue } \\
\text { (license/spectrum) fee }\end{array}$ & \\
\hline Bolivia & 1995 & 1995 & Partial & $1995-2001$ & $\mathbf{M}$ & $\mathbf{M}$ & D & 1995 & $\bar{Y}$ & Reg. fee & Ministry \\
\hline Brazil & 1997 & 1998 & Full & 1998 & $\mathbf{P}$ & $\mathrm{p}$ & $\mathbf{P}$ & 1997 & $\mathrm{Y}$ & Gvt + auction revenue & Ministry \\
\hline Chile & 1982 & 1987 & Full & None & Full & Full & Full & 1977 & $\bar{Y}$ & Gvt & Ministry \\
\hline Colombia & 1991 & Not yet & 0 & None & D & Full & $\overline{\mathrm{D}}$ & 1994 & $\mathbf{Y}$ & Reg. fee & Ministry \\
\hline Costa Rica & 1996 & Not yet & 0 & & $\mathbf{M}$ & $\overline{\mathrm{M}}$ & $\mathbf{M}$ & 1996 & $\mathbf{N}$ & Reg. Fee + gvt & Parliam. \\
\hline Dom. Rep. & 1998 & 1999 & Full & & Full & Full & Full & 1998 & $\bar{Y}$ & Auction revenue $+\mathrm{gvt}$ & $\begin{array}{c}\text { Public } \\
\text { controller }\end{array}$ \\
\hline Ecuador & 1995 & Not yet & 0 & $1995-2000$ & $\mathbf{M}$ & $\mathbf{M}$ & $\mathbf{P}$ & 1995 & $\mathrm{Y}$ & Auction revenue & Head of state \\
\hline El Salvador & 1995 & $1997 / 8$ & Partial & None & Full & Full & Full & 1997 & $\mathbf{N}$ & Auction revenue $+\mathrm{gvt}$ & Ministry \\
\hline Guatemala & 1995 & 1998 & Full & None & Full & $\mathbf{M}$ & Full & 1996 & $\bar{Y}$ & Auction fee & Ministry \\
\hline Honduras & 1996 & In process & 0 & 1995-2005 & Full & $\mathbf{M}$ & $\mathrm{D}$ & 1996 & $\bar{Y}$ & Gvt & Ministry \\
\hline Jamaica & & $1989-91$ & Full & & $\mathbf{M}$ & $\mathbf{M}$ & Full & 1995 & $\mathbf{N}$ & Reg. fee & Ministry \\
\hline México & 1990 & $1990-91$ & Full & $1990-1996$ & Full & Full & Full & 1996 & $\mathbf{Y}$ & Gvt & Ministry \\
\hline Nicaragua & 1995 & In process & & $1995-1999$ & $\overline{\mathbf{M}}$ & $\mathbf{M}$ & Full & 1995 & $\bar{Y}$ & Auction fee & $\begin{array}{l}\text { Head of } \\
\text { State }\end{array}$ \\
\hline Panama & 1995 & 1997 & Partial & $1997-2002$ & $\mathbf{M}$ & $\mathbf{M}$ & $\mathbf{P}$ & 1996 & $\mathbf{N}$ & Auction fee + gvt & Head of state \\
\hline Paraguay & 1995 & In process & 0 & & $\mathbf{M}$ & $\mathbf{M}$ & Full & 1995 & $\mathrm{Y}$ & Auction fee & Ministry \\
\hline Penu & 1991 & 1994 & Full & $1994-1999$ & Full & Full & Full & 1994 & $Y$ & Reg. fee & Ministry \\
\hline Venezuela & 1991 & 1991 & Partial & $1991-2000$ & $\mathbf{M}$ & $\mathbf{M}$ & Full & 1991 & $\mathrm{Y}$ & Reg. fee + gvt & Ministry \\
\hline Uruguay & $\begin{array}{c}1992 \\
\text { referendum } \\
\text { rejected } \\
\text { liberalizatio } \\
\mathrm{n}\end{array}$ & No & 0 & & $\bar{M}$ & $\bar{M}$ & Full & & $\bar{Y}$ & Gvt & Ministry \\
\hline
\end{tabular}

Level of competition: $M=$ monopoly, $D=$ duopoly, $P=$ partial competition, $F=$ full competition. These definitions are taken from ITU and refer to the number of licenceees rather than the actual degree of competition.

Source: Authors' compilation from ITU, regulator's web sites and World Bank internal documents 
Table 2: Evolution of selected partial performance indicators in the sector

\begin{tabular}{|c|c|c|c|c|c|c|c|c|c|c|}
\hline & \multicolumn{2}{|c|}{$\begin{array}{l}\text { Main telephone lines } \\
\text { per } 100 \text { inhabitants }\end{array}$} & \multicolumn{2}{|c|}{$\begin{array}{l}\text { Cellular subscribers } \\
\text { per } 100 \text { inhabitants }\end{array}$} & \multicolumn{2}{|c|}{$\begin{array}{l}\text { Faults per } 100 \text { main } \\
\text { lines per year }\end{array}$} & \multicolumn{2}{|c|}{$\begin{array}{l}\text { Residential } \\
\text { connection rate (US\$) }\end{array}$} & \multicolumn{2}{|c|}{$\begin{array}{l}\text { Residential monthly } \\
\text { Subscription fee (US\$) }\end{array}$} \\
\hline & 1990 & 1999 & 1990 & 1999 & 1991 & 1998 or 99 & 1996 & 1999 & 1996 & 1999 \\
\hline Argentina & 9.31 & 20.11 & 0.04 & 12.12 & 42.4 & 17.3 & 69 & 150 & 11.1 & 13.2 \\
\hline Bolivia & 2.76 & 6.17 & 0 & 5.16 & & & 168 & 131 & 5.5 & 1.7 \\
\hline Brazil & 6.5 & 14.87 & 0 & 8.95 & 4.5 & 3.2 & 1112 & 28 & 2.7 & 6 \\
\hline Chile & 6.6 & 20.7 & 0.11 & 15.05 & 97 & 52 & 258 & 159 & 15.3 & 16.3 \\
\hline Colombia & 6.91 & 16.03 & 0 & 7.53 & 80.4 & 56 & 321 & 181 & 2.9 & 3.8 \\
\hline Costa Rica & 10.05 & 20.41 & 0 & 3.53 & & 42.1 & 63 & 58 & 5.3 & 3.9 \\
\hline Dom. Rep & 4.76 & 9.81 & 0.04 & 5.02 & & & 98 & 98 & 6.6 & 6.6 \\
\hline Ecuador & 4.78 & 9.1 & 0 & 3.09 & 197 & 82 & 167 & 136 & 1 & 1.7 \\
\hline El Salvador & 2.42 & 7.61 & 0 & 6.22 & & & 297 & 331 & & 7.1 \\
\hline Guatemala & 2.13 & 5.51 & 0 & 3.05 & & & 258 & 223 & 0.7 & 0 \\
\hline Haití & 0.69 & 0.87 & 0 & 0.31 & & & & 48 & & 5.7 \\
\hline Honduras & 1.72 & 4.42 & 0 & 1.24 & 61.2 & 24 & 33 & 15 & 2.3 & 1.5 \\
\hline Jamaica & 4.46 & 19.91 & & 5.64 & 85.2 & & 16 & 16 & 6.6 & 2.7 \\
\hline México & 6.48 & 11.22 & 0.08 & 7.94 & 9.4 & 2.2 & & 111 & & 14.5 \\
\hline Nicaragua & 1.26 & 3.04 & 0 & 0.9 & & & 33 & 192 & 6.6 & 2.1 \\
\hline Paraguay & 2.66 & 5.54 & 0 & 8.13 & & & 822 & 561 & 3.3 & 4.8 \\
\hline Peru & 2.61 & 6.69 & 0.01 & 4.02 & 54 & 23.8 & 504 & 130 & 8.9 & 14 \\
\hline Uruguay & 13.43 & 27.07 & & 9.54 & & 5.6 & 382 & 89 & 9.1 & 8.5 \\
\hline Venezuela & 7.63 & 10.91 & 0.04 & 14.34 & & 3.5 & 39 & 101 & 2.5 & 9.5 \\
\hline USA & & $>100$ & & 31.55 & & 13.4 & & 44 & & 19.9 \\
\hline
\end{tabular}

Source: ITU 
Table 10: Universal Service Obligations in Latin America

\begin{tabular}{|c|c|c|c|c|c|c|c|c|c|c|c|c|c|c|c|c|c|c|}
\hline & \multirow{2}{*}{\multicolumn{2}{|c|}{ 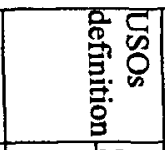 }} & \multirow{2}{*}{\multicolumn{2}{|c|}{ 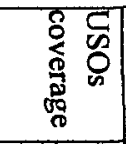 }} & \multirow{2}{*}{\multicolumn{4}{|c|}{ USOS OBLIGATIONS }} & \multirow{2}{*}{\multicolumn{4}{|c|}{ RETAIL SCHEME }} & \multicolumn{6}{|c|}{ FUNDING MECHANISM } \\
\hline & & & & & & & & & & & & & & & USOs & FUND & & \\
\hline & $Y$ & $\mathrm{~N}$ & 冚 & $\begin{array}{l}0 \\
\mathbb{9} \\
\stackrel{9}{9} \\
0\end{array}$ & 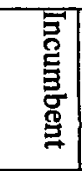 & 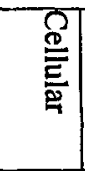 & 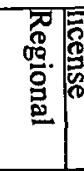 & 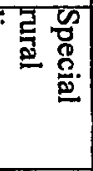 & 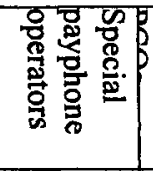 & 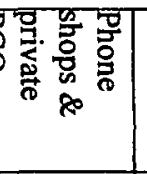 & $\begin{array}{l}\overrightarrow{0} \\
\frac{0}{8} \\
\frac{8}{2} \\
\stackrel{9}{7} \\
0 \\
0\end{array}$ & 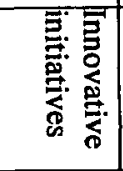 & 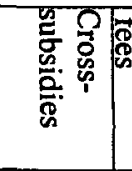 & 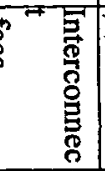 & $\mathbf{N}$ & $\mathrm{Y}$ & 可 & 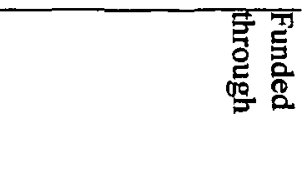 \\
\hline Argentina & $\mathrm{X}$ & & & $\mathrm{X}$ & $\mathrm{X}$ & & & & $\bar{X}$ & $\mathrm{X}$ & $\mathrm{X}$ & & $\mathrm{X}$ & & $\mathrm{X}$ & & & Pay or play \\
\hline Bolivia & $\mathrm{X}$ & & $\mathrm{X}$ & & $\mathrm{X}$ & & $x^{37}$ & & & & & & & & & $x^{38}$ & & Government \\
\hline Brazil & $\mathrm{X}$ & & $\mathrm{X}$ & & $x^{39}$ & & & & & & & $x^{40}$ & & & $\mathrm{X}$ & & & \\
\hline Chile & & $\mathrm{X}$ & & & & & & $\mathrm{X}$ & $\mathrm{X}$ & & $\mathrm{X}$ & & & $x^{41}$ & & $\mathrm{X}$ & & Central gvt \\
\hline Colombia & $\bar{X}$ & & & $\mathrm{X}$ & & & & $\mathrm{X}$ & & & & & & & & $x^{42}$ & & Operator levy \\
\hline Ecuador & & & & & $\mathrm{X}$ & & & & & & $\bar{X}$ & & & & & & $\bar{X}$ & $\begin{array}{l}\text { World Bank Technical } \\
\text { assistance }\end{array}$ \\
\hline El Salvador & & & & & & & & & & & $\mathrm{X}$ & & & & & & & \\
\hline \begin{tabular}{|l|} 
Dominican \\
Republic
\end{tabular} & $\bar{X}$ & & & & -43 & & & & & & $\mathrm{X}$ & & & & & $\bar{X}$ & & $\begin{array}{l}2 \% \text { tax on subsc. bills, } \\
\text { int'l settlements }\end{array}$ \\
\hline Guatemala & & & & & & & & $\mathrm{X}$ & $\mathrm{X}$ & $\mathrm{X}$ & & & $\underline{X}$ & & & $\mathrm{X}$ & & Spectrum auctions \\
\hline Honduras & & & & & - & & & & & $\mathbf{X}$ & & & & & & & $\mathrm{X}$ & - \\
\hline Peru & $\mathrm{X}$ & & $\mathrm{X}$ & & $\mathrm{X}$ & & & $\mathrm{X}$ & $\bar{X}$ & & $\mathbf{X}$ & & & & & $\mathrm{X}$ & & Operator levy \\
\hline Mexico & & $\mathrm{X}$ & $\mathrm{X}$ & & $\mathrm{X}$ & & & & & & $\mathrm{X}$ & & & $\bar{X}$ & $\mathrm{X}$ & & & $\begin{array}{l}\text { Virtual fund } \\
\text { considered } \\
\end{array}$ \\
\hline Nicaragua & & & & & & & & & & & $\mathrm{X}$ & & $\bar{X}$ & & & & $\mathrm{X}$ & $\begin{array}{l}\text { World Bank Technical } \\
\text { assistance }\end{array}$ \\
\hline Venezuela & $\mathrm{X}$ & & $\mathrm{X}$ & & $\bar{X}$ & -44 & & $\bar{X}$ & $\bar{X}$ & $\bar{X}$ & $\bar{X}$ & & & & & & & \\
\hline
\end{tabular}

37 Cooperatives with rural obligations.

38 Telecom law of 1997 has provisions for using El Fondo Nacional de Desarrollo Regional for funding rural telecoms, no evidence of actual implementation.

39 The incumbent operators, no obligations for the mirror license holders.

40 Virtual telephony.

41 To ensure the viability, payphone operators are planning to charge higher interconnection fees.

42 Social Telephony Fund.

43 DGT, Directorate-General of Telecommunications has operated rural telegraph system, but its to be discontinued.

${ }^{44}$ Cellular operators are permitted to serve rural areas, and have service expansion requirements.

Source: Estache, Foster and Wodon (2001) and data provided by Juan Navajas, The World Bank 


\section{Policy Research Working Paper Series}

Title

WPS2778 Technology and Firm Performance in Mexico

WPS2779 Technology and Skill Demand in Mexico

WPS2780 Determinants of Technology Adoption Gladys López-Acevedo in Mexico

WPS2781 Maritime Transport Costs and Port Efficiency

WPS2782 Global Capital Flows and Financing Constraints

WPS2783 Ownership, Competition, and Corruption: Bribe Takers versus Bribe Payers

WPS2784 Financial and Legal Constraints to Firm Growth: Does Size Matter?

WPS2785 Improving Air Quality in Metropolitan Mexico City: An Economic Valuation

WPS2786 The Composition of Foreign Direct Investment and Protection of Intellectual Property Rights: Evidence from Transition Economies

WPS2787 Do Farmers Choose to Be Inefficient? Evidence from Bohol, Philippines

WPS2788 Macroeconomic Adjustment and the Poor: Analytical Issues and CrossCountry Evidence

WPS2789 "Learning by Dining" Informal Networks and Productivity in Mexican Industry

WPS2790 Estimating the Poverty Impacts of Trade Liberalization
Gladys López-Acevedo

Gladys López-Acevedo

Ximena Clark

David Dollar

Alejandro Micco

Ann E. Harrison

Inessa Love

Margaret S. McMillan

Geroge R. G. Clarke

Lixin Colin Xu

Thorsten Beck

Asli Demirgüç-Kunt

Vojislav Maksimovic

The Mexico Air Quality Management Team

Beata K. Smarzynska

Donald F. Larson

Frank Plessmann

Pierre-Richard Agénor

Somik V. Lall

Sudeshna Ghosh

Jeffrey J. Reimer
Author
Date

Fèbruary 2002

February 2002

February 2002

February 2002

February 2002

February 2002

February 2002

February 2002

February 2002

February 2002

February 2002

February 2002

February 2002
Contact

for paper

M. Geller 85155

M. Geller 85155

M. Geller 85155

E. Khine 37471

K. Labrie 31001

P. Sintim-Aboagye 37644

A. Yaptenco 38526

G. Lage 31099

P. Flewitt 32724

P. Kokila 33716

M. Gosiengfiao 33363

Y. D'Souza 31449

P. Flewitt 32724 


\section{Pollcy Research Working Paper Series}

Title

WPS2791 The Static and Dynamic Incidence of Vietnam's Public Safety Net

WPS2792 Determinants of Life Insurance Consumption across Countries

WPS2793 Agricultural Markets and Risks: Management of the Latter, Not the Former

WPS2794 Land Policies and Evolving Farm Structures in Transition Countries

WPS2795 Inequalities in Health in Developing Adam Wagstaff Countries: Swimming against the Tide?

WPS2796 Do Rural Infrastructure Investments Jocelyn A. Songco Benefit the Poor? Evaluating Linkages:

A Global View, A Focus on Vietnam

WPS2797 Regional Integration and Development Maurice Schiff

Thorsten Beck lan Webb

Panos Varangis Donald Larson Jock R. Anderson

Zvi Lerman Csaba Csaki Gershon Feder in Small States
WPS2798 Fever and Its Treatment among the
More or Less Poor in Sub-Saharan
WPS2798 Fever and Its Treatment among the
More or Less Poor in Sub-Saharan Africa
WPS2799 The Impact of the Indonesian Financial Crisis on Children: Data from 100 Villages Survey
WPS2800 Did Social Safety Net Scholarships Reduce Drop-Out Rates during the Indonesian Economic Crisis?
WPS2801 Policies to Promote Saving for Retirement: A Synthetic Overview

Deon Filmer

Lisa A. Cameron

Lisa A. Cameron

Dimitri Vittas

\section{Date}

February 2002

February 2002

March 2002

March 2002

P. Sader

March 2002

March 2002 33902

P. Sader 33902

P. Infante 37642

Contact for paper

H. Sladovich 37698

A. Yaptenco 31823

P. Kokila 33716

M. Fernandez 33766

H. Sladovich 37698

H. Sutrisna 88032

P. Flewitt 32724

H. Sladovich 37698

der

